\title{
A KOCKÁZAT ELBIZONYTALANODÁSA ÉS A BIZONYTALANSÁG NÖVEKVỐ KOCKÁZATA A GAZDASÁGI DÖNTÉSEKBEN
}

Bélyácz Iván - Daubner Katalin ${ }^{1}$

\begin{abstract}
ABSZTRAKT
Tanulmányunk azt az elméleti fejlődési utat követi nyomon, amely a kockázat és bizonytalanság közgazdaságtani helyzetében végbement Knight (1921) és Keynes (1921) művének megjelenésétől egészen a legutóbbi időkig. A kiindulást a klaszszikus közgazdaságtan gondolkodóinak vonatkozó megjegyzései jelentik. Ezt követi a Knight és Keynes nevéhez füződő fordulat taglalása és a kockázatvállalás elméleti gyökereinek feltárása. A kifejtés egyik lényegi fejezete a szerzők kísérlete az „animal spirits” kockázatviselési szándékként történő újraértelmezésére. Külön fejezet szól a racionális választás és a kockázat kapcsolatáról, egy másik rész pedig a kockázat közgazdaságtani kanonizálásáról. A tanulmány további részei vizsgálják a kockázat és bizonytalanság különbségének relativizálására irányuló szándékokat, a bizonytalanság negligálását a neoklasszikus eszmerendszerben, a kockázat és bizonytalanság egybeolvasztási kísérleteit, valamint a kockázatvállalás és kockázatviselés egységének megbomlását. A szerzők végső soron arra a meggyőződésre jutnak, hogy Knight és Keynes kockázati és bizonytalansági tanai időtállónak bizonyultak.
\end{abstract}

JEL-kódok: B26, D81, E12, Goo, G11

Kulcsszavak: kockázat, bizonytalanság, kockázatvállalás, kockázatviselés, animal spirits, racionális választás

1 Bélyácz Iván akadémikus, egyetemi tanár, a Magyar Tudományos Akadémia rendes tagja. E-mail: belyacz@ktk.pte.hu.

Daubner Katalin egyetemi docens, kandidátus. E-mail: daubnerkati@gmail.com. 


\section{BEVEZETÖ GONDOLATOK}

Éppen száz évvel ezelött jelent meg Frank Knight: Risk, Uncertainty and Profit és John Maynard Keynes: Treatise on Probability címü müve a kockázatról és bizonytalanságról, valamint a valószinüség fogalmáról.

Gondolataik ma is élők és inspirálók. E tanulmány tisztelgés e két nagy gondolkodó korszakalkotó munkássága előtt.

A kockázat számos tudományágban előforduló fogalom², ám minden technikai diszkusszió három komponenssel reprezentálható: először egy vagy több potenciális nehézségkeltő (néha hazárdnak is nevezik); másodszor annak valószínűsége, hogy ezek a nehézségkeltők aktivizálódnak (gyakran nevezik kitettségnek); harmadszor a valószínű ellenhatás, ami akkor jelentkezik, ha a nehézségkeltés bekövetkezik. A kockázatot szokásos a veszteség nagysága alapján összehasonlítani (Kimmons, 2003). Az első világháború előtt a gazdasági rendszert úgy írták le, mint amelyben nincs kockázat. A gazdasági rendszeren belül a tartós béke (a megfelelő időben) tökéletes kondíciókat nyújtott a döntéshozatalhoz. Az első világháború során és utána megváltozott a valószínűség megítélése, valamint a kockázat szemlélése a gazdasági rendszerben, s a kockázat megértésének új koncepciói jelentek meg a bizonytalanság és a racionális döntéshozatal képében.

A nagy törés akkor következett be a kockázat értékelésben, amikor a világháború darabokra zúzta a megelőző időszak konvencionális bölcsességét. A világról, amely egykoron előre-jelezhetőnek és rendezettnek látszott, egyszer csak kiderült, hogy nem elörejelezhető, és szélső esetben rendezetlen, ahogy Bernstein (1995:10) is írja. Egyáltalán nem véletlen, hogy Knight (1921) nagy művének központi témáját így vezette be:

„sok kérdés merül fel annak kapcsán, hogy egyáltalán meddig lehet eljutni a világ megismerésében (...) csupán nagyon speciális és kritikus esetekben, mint amilyen a matematikai tanulmányozás, esetleg megtehető.”

Az sem véletlen, hogy Keynes (1921) valószínűségi műve lényegében támadás volt annak ideája ellen, hogy a matematika - valamilyen fokú bizonyossággal - képes definiálni a jövőt.

2 A kockázatot és a bizonytalanságot egyaránt használják fogalomként a döntéshozatalban és a köznapi életben. Ez utóbbi esetben a szavak hétköznapi használata mindazonáltal jelentősen eltér a szakmai-tudományos definícióktól. Az Oxford English Dictionary a kockázatot olyan „helyzetként” írja le, „amely veszélynek kitettséget hordoz magában”, a bizonytalanságot pedig úgy definiálja, mint olyan „állapotot, amelyre nem lehet támaszkodni, nem ismert és nem definiálható”. 
Mehr-Hedges (1962) a vállalati kockázatmenedzselési döntések kezelésével kapcsolatban fontos alapelveket fogalmazott meg. Az első szerint a döntéshozó ne kockáztasson többet, mint amekkora veszteséget megengedhet magának. A második elv alapján a döntéshozó ne kockáztasson kevésért. A harmadik szerint a döntéshozó legyen tekintettel a tétekre. Az első alapelv kapcsán a döntéshozó legyen képes becsülni a kockázati kitettségből származó veszteségpotenciált; a másodikhoz tartozóan mérnie kell azokat az erőforrásokat, amelyek rendelkezésre állnak e potenciál ellentételezésére; harmadszor a döntéshozónak képesnek kell lennie olyan eszközök kifejlesztésére, amelyek mérik az alternatív kockázatvállalási esetek költségeit és hozamait adott kockázati szituációban.

A kockázat és bizonytalanság közötti alapvetö különbség a lehetséges döntési kimenetek sorozatának s bekövetkezési valószínűségüknek a kvantifikálhatóságán alapszik. A bizonytalanság gyakran a döntéshozatal nem könnyü számszerüsíthetőségére utal. Knight (1921) állítása szerint bizonytalanság egyaránt lehet a döntési kimenetekkel és azok bekövetkezési valószínüségével kapcsolatban. Ugyancsak lehet bizonytalanság a döntéshozók preferenciáival összefüggésben (March, 1978). A kvantifikálhatóság a kockázat kulcskarakterisztikája, ám a kockázat definíciója és a kockázat mérése között nem lineáris a kapcsolat. A valóságban a kockázat definiálásának folyamata döntési mozzanatot tükröz, amely függ a döntéshozó attitüdjétől, az alapul vett termelési eljárástól, $s$ a döntési probléma jellegzetességeitől (Tischof et al., 1984). Ezek a tényezők befolyásolják a kockázat definiálásának kétlépéses folyamatát; az első lépésben meg kell határozni, hogy mely konzekvenciák vagy kimeneti dimenziók foglaltatnak benne; b) a következő lépés az első fázisban kiválasztott konzekvenciákon alapuló kockázati indikátorok konstruálása.

Bernstein (1995:11) szerint egy olyan világban, ahol a változások gyorsabbak annál, mint azt bárki érteni lenne képes, a kockázat kevésbé megközelíthetőnek látszik mérési szempontból, mint azt a befektetők többsége hinné. Az eredmény az lesz, hogy a kockázatmenedzselés szokásos és hiteles módszerei defenzívába kerülnek, éppen ezért a kockázattól tartózkodás minden korábbinál intenzívebbé válik. Ugyanakkor a kockázatot tartalmazó, új termékek (befektetési változatok) iránt robbanásszerü kereslet nyilvánul meg, s a két törekvés eredőjeként a piacok inkább kockázatosabbá válnak, mint nem. 


\section{A KOCKÁZAT ÉS BIZONYTALANSÁG MEGJELENÉSÉNEK ELÖTÖRTÉNETE A KÖZGAZDASÁGTANBAN}

A közgazdaságtan még nem létezett önálló tudományszakként, amikor Daniel Bernoulli (1738) műve megalapozta a kockázat melletti emberi döntéshozatal fundamentális teóriáját, amelyre ma a kockázati tartózkodás és a várható hasznosság elmélete kezdeteként tekintenek. Bár Adam Smith (1776) korszakalkotó művét a közgazdaságtan első alkotásaként kezelik, munkáját általában nem hozzák összefüggésbe a kockázattal. Annak ellenére sem, hogy ez a mű fontos utalást tartalmazott a kockázatra vonatkozóan (Sakai, 2018: 8).

Általánosságban megállapítható, hogy a klasszikus közgazdaságtanban a kockázat koncepciója - legalábbis a közgazdaságtan gondolkodói között - még rejtélyes volt. A kockázat, a hazárd, a bizonytalanság és az esély ritkán jelent meg szinonimaként a kézikönyvekben. Adam Smith a kockázat koncepciójára a következő definíciót adta:

„Azt a jövedelmet, amit a (...) készletből származtatnak, ama személy által, aki menedzseli vagy használja azt, profitnak nevezik. Ha olyan személy származtatja, aki nem maga használja, hanem bérbe adja másnak, akkor azt kamatnak nevezik (...). E profit egy része természetesen a kölcsönvevőt illeti, aki vállalja a kockázatot, s viseli a használatból eredő kárt, a másik része a kölcsönadóé, aki lehetőséget ad a kölcsönvevőnek profit realizálására” (Smith, A., 1956; 1776:55).

Röviden kifejezve: a kockázatos piacokon a profit (és a veszteség) tendenciaszerűen magasabb, bár tény, hogy ezek a piacok sok befektetőt vonzanak, s ez az oka annak, hogy

„versengésük ama szint alá csökkenti a profitot, ami még elegendő lenne a kockázat ellensúlyozásához" (Smith, A., 1776:117).

Sakai (2018) megjegyzi, hogy Smith nem részletezte vonatkozó megfontolásait, ám azok így is elegendőek annak a demonstrálására, hogy Smith perspektívájában a kockázat miként vonzza azt az elemet, amely igazolja a vállalkozó által nyert jövedelem egy részét. Az a tény, hogy az emberek hajlanak arra, hogy kockázatvállalók legyenek, oda vezet, hogy csökkenni fog a kockázatos tevékenységböl származó profit.

David Ricardo a vállalkozókra utalva megfigyelte a profitcsökkenés konzekvenciáját:

„A vállalkozók felhalmozási motivációja csökkenni fog a profit minden mérséklődésével, s azzal együtt meg is fog szünni, amikor a profit olyan alacsony lesz, hogy nem fogja biztosítani a megfelelő kompenzációt a károkért és azért 
a kockázatért, amit szükségképpen viselniük kell a tőke produktív használata során" (Ricardo, 1821:123).

John Stuart Mill már több figyelmet szentelt a kockázat koncepciójának, vizsgálva annak kapcsolatát a profittal:

„A profit rátája nagymértékben meghaladja a kamatrátát. A többlet valamilyen mértékü kompenzáció a kockázatért. Az egyén - tőkéje kölcsönadásával - csekély kockázatot vállal, vagy egyáltalán nem vállal kockázatot. Ha viszont üzletbe kezd saját kockázatára, akkor mindig kiteszi tőkéjét (...) a részleges vagy teljes veszteség veszélyének. Öt ezért a veszteségért kompenzálni kell” (Mill, 1885:406).

Az említett elméleti hozzájárulások elegendőek annak kimondásához, hogy a klasszikus közgazdaságtanban egyetértés volt a profit természete és az ehhez kapcsolódó vállalkozói kockázat közötti reláció tekintetében. Eszerint a kockázat képes volt legalább részben igazolni annak a (pozitív vagy negatív) különbségnek a létezését, ami a javak piaci ára és költsége között volt.

Az 1870-es években a klasszikus közgazdaságtani iskola ellen kihívást intézett egy új megközelítés a közgazdasági elméletben: a marginalizmus. A paradigma átalakulása a kockázat szemlélésének a klasszikustól eltérő útját követte. Menger a vállalkozói funkciót vizsgálva a következőket írta:

„Nem tudok egyetérteni Mangoldt véleményével, aki a kockázatvállalást úgy jelöli, mint a vállalkozás lényegi funkcióját a termelési folyamatban, minthogy ez a kockázat csupán eseti, s a veszteség esélye kiegyensúlyozódik a profit reményével” (Menger, 1871:161).

Roggi-Ottanelli (2013) kiemeli, hogy a marginalista iskola gondolkodóinak világában nagyon szűk tér maradt a kockázat és bizonytalanság számára. A marginalista közgazdászok igazán nem fordítottak figyelmet a kockázat és bizonytalanság megfontolására. A marginalisták annak tudatában, hogy a kockázat és bizonytalanság bennfoglalása modelljeikbe potenciálisan negatív konzekvenciákkal járhat, a problémát megkerülve, azokat áttették az egyszerü feltevések közé.

\subsection{Fordulat a kockázat és bizonytalanság közgazdaságtani kezelésében: Knight és Keynes}

A klasszikus elmélet gondolkodói túlbecsülték a piacgazdaság stabilitását, beleértve azokat a területeket, ahol az eredmények egyértelmüen bizonytalanok voltak, s ahol nem irányították determinisztikus vagy kauzális törvények a gazdasági életet és a döntéshozatalt. Ebben hozott fordulatot Knight (1921) és Keynes (1921) műve. Knight (1921) szerint a kockázat és bizonytalanság között így tehető különbség: 
„Ahhoz, hogy megőrizhető legyen a már megfogalmazott megkülönböztetés (...) a mérhető bizonytalanság és a nem mérhető között, a ,kockázat' kifejezést használhatjuk az első jelölésére, a bizonytalanság elnevezést az utóbbira (...). A gyakorlati különbség a kockázat és bizonytalanság kategóriája között abban áll, hogy az első esetben a kimenet eloszlása - az események csoportjában ismert (vagy elözetes kalkuláció révén, vagy múltbeli tapasztalati statisztikákból), míg a bizonytalanság esetében ez nem igaz, s az ok általában az, hogy lehetetlen csoportokat formálni az eseményekből, mivel az érintett szituáció nagymértékben egyedi" (Knight, 1921:233-234).

Szemben a kockázattal, a bizonytalanság fundamentálisan eltérő koncepció volt abban az értelemben, hogy nem volt mérhető. Ez a nem mérhető jelenség nem volt más, mint „tényleges bizonytalanság”. Knight (1921) - könyvének fö témájaként létrehozta a knighti közgazdaságtan magvát: a bizonytalanság kulcsfogalomként szolgált a piacgazdaság hatékonyságának és korlátainak megértéséhez. Knight sajnálkozott azon, hogy a nem mérhető bizonytalanságot az idáig negligálták a közgazdasági életben. Sakai (2018) kiemeli, hogy miután a bizonytalanságot valós szituációkra alkalmazták, karakterének meg kellett változni. Utána jelent meg a termelő ember új, feltörekvő típusa, s ezt az egyént vállalkozónak nevezték, akinek elöretekintő karaktere volt az elöre jelezhetetlen világban. Ekkor ő maga merész akcióra vállalkozott, ami extraprofitot eredményezhetett, ha előrejelzése pontosnak bizonyult.

Knight (1921) szerint a bizonytalanság a profit létezésének szükséges feltétele. Szerinte, ha a jövő csupán kockázatos, akkor profit nem létezhet. Művéből vett két idézet támogatja ezt az interpretációt:

„az igazi bizonytalanság és nem a kockázat az, (...) ami alapot szolgáltat a profit valós teóriájához és számít az aktuális és teoretikus verseny közötti divergenciában" (Knight, 1921:20).

Így folytatja:

„mivel a kockázat a szokott értelemben nem akadályozza meg a tökéletes tervezést, így a kockázat nem gátolhatja a kompetitív erők tendenciáinak teljes realizációját, vagy a profit növelését" (Knight, 1921:2).

Knight szerint a profit egy maradék: a gazdasági cselekvés tényező kifizetése, jutalom a kockázat vállalásáért, amelyet a vállalt kockázat nagysága arányában realizálnak. Eszerint - habár az összes jövedelem szükségképpen nem ismerhető elöre - az mindig jutalomnak tekinthető mérhető funkcióért vagy cselekedetért.

Knight számára a kockázat és bizonytalanság közötti megkülönböztetés kapcsán a szubjektív valószínűségeknek nincs semmilyen funkciója: 
„az üzleti döntések (...) olyan helyzetekre vonatkoznak, amelyek - általánosan fogalmazva - túl egyediek ahhoz, hogysem statisztikai táblák sorával iránymutatás lenne adható" (Knight, 1921:231).

Felismerte: egyáltalán nem nyilvánvaló, hogy amikor az események elég hasonlók, akkor támogathatnak egy „objektív” valószínűséget. Az események egyediségéről és csoportosíthatóságáról így ír:

„A tapasztalat univerzumában semmi nem abszolút egyedi, mint amennyire két dolog abszolúte különböző. Következésképpen mindig van lehetőség osztályok formálására, ha a korlátokat leengedik, s a hasonlóság interpretációjának vesztesége elfogadható" (Knight, 1921:227)³.

Knight nem véletlenül volt kétlelkű az események osztályba sorolhatóságát illetően. Egyik oldalról elfogadta az ismétlődő események csoportosithatóságát és valószínűségi alapú minősítését, ám az üzleti döntések viszonylatában az egyediséget hangsúlyozta.

Knight kockázati-bizonytalansági diszkussziójának korában csak a legkorábbi fázisban volt jellemző a tulajdonlás és müködtetés elválása. Knight felismerte, hogy ugyanazok a tényezők, amelyek akadályozzák a vállalkozás biztosithatóságát, egyben okozói annak a problémának, hogy a részvénytulajdonosok a vállalkozás müködtetését fizetett menedzserekre bízzák. Le Roy-Singell (1987:395) szerint ez azt jelentette, hogy Knight érzékelte a tőkeműködtetőknek a tulajdonosoktól való elkülönülését, a megbízó-ügynök probléma megfogalmazásáig azonban nem jutott el, sőt tagadta a kettő elválásának létezését. Ezt igazolja Knight idevonatkozó véleményének felidézése:

„Itt van egy nyilvánvaló funkcióelválasztás a döntéshozatalban s a döntésbeli hiba ,kockázatának' vállalásában. A szeparáció egészen élesen látszik az alkalmazott menedzserek esetében. (...) Kisebb vizsgálódás megmutatja, hogy ez a szeparáció illúzió, amikor az irányítás pontosan definiált és telepített, akkor a döntéshozatali funkciók $s$ a felelősségvállalás azok pontosságáért egynek és oszthatatlannak találtatnak" (Knight, 1921:293-294).

„Minden olyan esetben, amikor nyilvánvaló szeparációt találunk az irányítás és a bizonytalanságviselés között, akkor a vizsgálódás kimutathatja, hogy mi lényegében összezavarjuk a rutinműveleteket a valós irányítással" (Knight, 1921:298).

3 KNIGHT kételkedése tükröződik a következő idézetben: „Itt az a megkülönböztetés, hogy nincs semmilyen hiteles alap az esetek osztályozásához. A valószínűségnek ez a formája okozza a legnagyobb logikai nehézséget az egészben, $s$ ennek nincs kielégítő diszkussziója, ami megadható lenne, ám annak megkülönböztetését a többi típustól hangsúlyozni kell, s néhányat jelezni komplikált relációi közül” (Knight, 1921:225). 
Knight tagadása azt illetően, hogy a fizetett menedzserek lényegében vállalkozói funkciókat is gyakorolnak, vitatható, mivel a nagy korporációkban a tulajdonosok és a hitelezők képviselői hatalmuk nagy részét delegálják fizetett menedzsereknek. Ez kevésbé volt nyilvánvaló Knight korában, manapság annál inkább.

Knight bizonytalanságról szóló tanítása, s az a megállapítása, hogy a bizonytalanság értelmet ad minden gazdasági cselekvésnek, nemcsak a keletkezés korában találkozott elutasítással, de a későbbi korok jeles képviselői által sem volt teljességgel elfogadott. Ezzel összefüggésben érdemes felidézni Hirshleifer-Riley (1995) szavait a huszadik század végéről:

„Az itteni megközelítés nem engedi meg a bizonytalanság vagy zavar pszichológiai értékelését, amelytől az emberek gyakran szenvednek, amikor bizonytalan (kockázatos) kimenetű szituációkkal szembesülnek. A modellünkben az egyén nem is bizonytalan és nem is zavart. Amikor felismeri, hogy tudása nem tökéletes, így nem lehet bizonyos afelől, melyik állapot fog bekövetkezni. Ő mindazonáltal pontos numerikus valószínüséget kapcsolhat hozzájuk, reprezentálva hitének fokát minden lehetséges állapot valószínüségeként. Mentségünk arra, hogy nem ábrázoljuk a bizonytalanságot vagy zavart, az lehet, hogy mi a közgazdaságtant igyekszünk modellezni, és nem a pszichológiát" (1995:7).

Knight (1921) valószínűségi álláspontja különleges és bonyolult volt: valahol a szubjektív és objektív elmélet között helyezkedett el. Ö úgy gondolta, hogy a valószínűségi koncepció a társadalomtudományokban alapvetően különbözött a természettudományokban alkalmazottól. Keynes diszkussziója túlment ezen, s felvetette a bizonytalanság egy nagyobb kihívást okozó koncepcióját. Az ő véleménye szerint a bizonytalanság nem csupán nem számszerü és nem összehasonlítható mint valószínűség, hanem egyben egy „vad fogalom”, amely magában foglalja az „animal spiritset”, vagyis a spontán optimizmust (vö. Marchionatti, 1999). Jeronimo (2014:3) szerint Keynes, hogy hangsúlyozhassa a redukálhatatlan bizonytalanságot, a várakozások volatilitását, különösen a mások várakozásaival kapcsolatos várakozásokat (jórészt indeterminálatlanul), bevezette az „animal spirits” fogalmát, egy olyan ideát, amelyet nem fogadtak túlzott lelkesedéssel abban a korban. Az animal spirits „ördögi fondorlatnak látszott, egy önkényes elemnek, amelyet azért vezetett be, hogy a történet kedvező fordulatot vegyen”, ahogy azt Koppl (1991:204) magyarázta. Mindazonáltal Keynes számára az animal spirits (vagy a tudat állapota, ösztön, hit, kényszerítés) „spontán sürgetést okoz a cselekvésre inkább, mint a nem cselekvésre, s nem a kimeneti kvantitatív előnyök súlyozott átlaga, ha az előnyöket kvantitatív valószínűségekkel szorozzuk" (Keynes, 1936:161). 
Modern szóhasználattal Keynes nézete az volt: a nagy ugrás az, hogy a döntési szituációkat a bizonytalansággal jellemezhetöen kezelik, vagy olyan helyzetként, amely csak kockázatot foglal magában. Bármely választás a jövőbeni alternatívák közül fundamentálisan bizonytalan, mivel a jövő logikailag megismerhetetlen. Nem áll rendelkezésre a jövőből vett, olyan minta, amely megismerhetővé tenné a jövőbeni alternatívák valószínűségét, így nincs mód a bizonytalansági probléma olyan redukálására, amely a kockázatot magában foglaló problémává tenné, véli Weintraub (1975:532).

Keynes azt állítja, hogy a bizonytalanságot magukban foglaló, tradicionális elméleti szituációkban azt a kockázat kezelésére alkalmas valószínűségi módszerrel vizsgálták. A tradicionális elmélet feltételezte, hogy valaki maximalizálhatja a várható kifizetéseket annak ellenére, hogy a várható értékek nem számíthatók megbízhatóan. Míg az egyéneknek ma kell cselekedniük, választásaik viszont csak a jövőben válnak ismertté, ám az összes - adott időben történő - gazdasági cselekvésnek intertemporális következményei vannak. A gazdasági egyénnek a döntéseit valamire alapoznia kell, s ez a valami vagy a közeli múlt, vagy az, amit mások csinálnak. Erről a választási keretfeltételről viszont Keynes kritikusan nyilatkozik: „... az a valami nagyon ingatag alapra épülhet, s ki van téve hirtelen és erőszakos változásoknak” (Keynes, 1937:214).

A bizonytalanság döntésbeli jelentőségét Keynes a következőkkel indokolja:

„Elméletem annak összegzésével jellemezhető, hogy adott társadalomlélektan, kibocsátási szint és a foglalkoztatás együtt a beruházástól függ. (...) (Habár néhány más tényező is befolyásolhatja a kibocsátást), ezek azok, amelyek meghatározzák a beruházási arányt, bár kevésbé megbízhatóak, mivel ezek azok, amelyeket befolyásolnak a jövővel kapcsolatos nézeteink, bár arról a jövőröl keveset tudunk" (Keynes, 1937:221).

Keynes állítása szerint „az emberek a gyakorlatban figyelmen kívül hagyják a bizonytalanságot: ők úgy cselekszenek, mintha a várható megtérülési értékek fixek lennének. A várható értékek számítása olyan feltevéssel történik, hogy a jövőbeni kimeneteket a megtérülési értékek stabil eloszlásából származtatják. Az egyének tudják, hogy az eloszlások nem fixek, mégis - jobb választás hiányában - úgy cselekszenek, mintha mögöttük a várható előnyök és hátrányok jó benthemita kalkulációja állna, s mindegyik szorozva a neki megfelelő valószínűséggel, várva a szorzatok összegzését” (Keynes, 1937:214).

Keynes (1921:8. fejezet) elutasította a relatív gyakorisági teóriát, mivel

„ha megengedjük, hogy ez uralja a területet, akkor azt is meg kell engednünk, hogy a valószínüség nem útmutató a cselekvéshez; ha ezt követeljük, akkor nem okszerűen fogunk cselekedni”. 
Ezzel azt állította szembe, hogy a valószínűség nem a kedvező és kedvezőtlen bizonyítékok egyenlege, hanem

„az abszolút releváns tudástömeg és a relatív tudatlanság egyenlege, s az új bizonyítékhoz hozzájutás növeli az argumentum súlyát. Az új bizonyíték időnként csökkenti az argumentum valószínűségét, ám mindig növeli annak súlyát” (Keynes, 1921:28).

Keynest munkássága kezdetétől foglalkoztatta a beruházások kockázata, s egy korai cikkben - (1910) - véleményt nyilvánított a tárgyról:

„A kockázat, amelyet figyelembe kell venni, az szubjektív kockázat, érzület, amely - mondjuk - a befektető oldalán van, s annak nagysága nagyon nagy mértékben függ a számára könnyen elérhető, a befektetésre vonatkozó, releváns információk mennyiségétől. Ami kockázatos beruházás volna a tájékozatlan spekuláns számára, az kivételesen biztonságos lenne egy jól informált szakértő számára. A kockázat nagysága - bármely befektető szemszögéből valójában alapvetően függ saját tájékozatlansága fokától, tekintettel a vizsgált befektetés körülményeire és kilátásaira" (Keynes, 1910:46).

Azt állítja, hogy a jövőbeni beruházási hozamok rendszerint nem nyerhetők meg az eredeti várakozások szerint. Számára az a fontos, hogy az a tudás, amely formálja az aktuális beruházási döntések bázisát, rendszerint nagyon szűk. Javaslata szerint „az ilyen jellegű helyzetekben jobb olyan tények által vezéreltetve lenni, amelyek iránt viszonylag nagyobb a bizalmunk, még akkor is, ha azok kevésbé határozottak a kérdés szempontjából, mint mások" (Keynes, 1936:148). Ezek a tények úgy lépnek be, hogy a befektetők visszazuhannak a konvenciók talajára:

„... feltéve hogy a meglevő állapotok folytatódnak határozatlan ideig, kivéve addig a fokig, hogy azoknak okuk lenne a változásra” (Keynes, 1936:152).

Runde (1990:289) idézi Keynes véleményét a benthamita-mód tévedésnek minősítéséről; ez tükröződött Keynes (1937) nevezetessé vált „Galton Lecture” előadásában.

„Habár volt egy alkotóelem a tizenkilencedik század önelégültségében, az, (...) hogy elfogadták a benthamita iskola rendkívüli konstrukcióját, amely szerint az alternatív cselekvési irányok összes lehetőségéhez először hozzákapcsolható egy szám, amely kifejezi a kérdéses cselekvési irányból következő valószínűséget. Így összeszorozva az adott cselekvés összes lehetséges konzekvenciájához kapcsolt számokat és összegezve azokat, felfedezhetnénk azt, hogy mit tegyünk. Ezen a módon a valószínű tudás mitikus rendszerét alkalmazták, hogy a jövőt ugyanolyan kalkulálható állapotra redukálják, mint amilyen a jelen. Ámbár éppen manapság hiszem, hogy gondolatainkat időnként befolyásolják ilyen pszeudoracionális megjegyzések" (Keynes, Galton Lecture, 1937:124). 
A Knight-Keynes-fordulat lényegéről megállapíthatjuk, hogy egyik oldalról Knight szerint a kockázatot és bizonytalanságot el kell választani egy olyan feltörekvő rendszerben, ahol többé nem érvényesült a teljes bizonyosság. Ö arra a tényre fordította a figyelmét, hogy a döntéshozóknak tekintettel kell lenniük a jövőbeni események hatásaira, s nem támaszkodhatnak kizárólag a múltbeli bekövetkezésekre a jövőbeni események meghatározásában.

Keynes - másik oldalról - figyelmen kívül hagyta az „események” kifejezést, s ehelyett az állításokat preferálta, amelyek a jövőbeni eseményekre helyezik a hangsúlyt. Ö határozottan ellenezte a múltbeli események matematikai analízisét, s azt, hogy ezek eredményeit gazdasági döntésekhez felhasználják. Keynes közgazdasági nézetei teljességgel a bizonytalanságra fókuszáltak. Ő kritizálta az eseményeken alapuló elemzést, s üdvözölte az állításokon nyugvó előrelátást. Keynes azt állította, hogy a valószinüségnek nincs hatása a való élet történéseire: egyszerüen azért, mert bár a hasonló események ismétlödöen történnek, azonban nincs garancia azok jövőbeni megfigyelhetőségére.

Knight és Keynes egyaránt igyekezett kiküszöbölni a korábbi teóriák hiányosságait a kockázat gazdasági rendszerbeli szerepét illetően. Új bizonytalansági koncepciójukkal megkíséreltek változtatni az akkor uralkodó felfogáson, hogy ti. annak értelmében a kockázat nem kapcsolódik a gazdasági rendszerbeli döntéshozatalhoz. Chapman (2019:5) kiemeli Knight és Keynes érdemét abban, hogy felvetették a döntési rendszer sebezhetöségének lehetőségét a meglepetés elemének köszönhetően. Keynes szerint egy olyan rendszer, amely nem alapozódhat a múltbeli történések gyakorisági eloszlására, különösen sebezhető a meglepetés tekintetében, s így volatilissé válik.

A klasszikus iskola és a Knight-Keynes-fellépés közötti sajátos átmenetként értelmezhető a Haynes (1895) cikkében tett megkülönböztetés („kockázat, amely statikus állapotú társadalomban érvényesülhet”, p. 412) és a dinamikus kockázat („veszély kockázata, ami közvetlenül a dinamikus változásoknak tulajdonítható” p. 412$)^{4}$.

4 „A statikus arra tendál, hogy csökkentse a kockázatot a haladással, ám a kockázatok szubjektív becslése általában, valamint a dinamikus kockázatok száma és volumene tendenciaszerüen növekszik úgy, hogy a kockázat fontossága a gazdasági életben várhatóan inkább növekedhet, mint csökkenhet" (HAYNES, 1895:449). 


\subsection{A döntéshozói kockázatvállalás elméleti alapjai}

A kockázat közgazdaságtani és vállalkozásbeli szerepének vizsgálatakor elkerülhetetlen szükségszerűség a kockázatvállalás és kockázatviselés elméleti gyökereinek feltárása, a vállalkozói kockázat eredetének kiderítése. Keynes korábban exponált vállalkozói karakterizációja erős hasonlóságot mutat Marshall és Schumpeter vállalkozói magatartásra vonatkozó analízisével. Marshall (1890) müvében a vállalkozóra úgy tekint, mint aki a túlélésért folytatott küzdelemben választódik ki: „alkalmas/képes ember, akit a jó szerencse hatása is segít” (Marshall, 189o:15), s mint aki rendelkezik a következő kvalitásokkal:

„... felkészültség, ötletesség, készséges sokoldalúság” (Marshall, 1890:305);

„széleskörü ítélőképesség, erőforrás, gondosság, a szándék állhatatossága” (Marshall, 1890:312).

A vállalkozó megragadja

„a lehetőséget bátorsággal és bölcsességgel, s profitábilis kalanddal” (Marshall, 1890:601).

Schumpeter azt írja, hogy a gazdasági életben

„mindenféle siker az intuíciótól függ, a dolgok olyan látásától, amelyről utóbb kiderül, hogy helyes volt, annak ellenére, hogy jelenleg nem állapítható meg” (Schumpeter, 1934: 85).

Schumpeter hangsúlyozza, hogy a vállalkozó fundamentális karakterisztikája olyasvalakit reprezentál, aki a szokásos csatornák mögé tekint, akinek van intuíciója és képessége korrigálni a jövő trendjeinek előrejelzését elégséges információs bázis nélkül.

Prezentálása alapján a vállalkozó motivációja megfelel a keynesi „animal spirits” specifikációjának - azaz a „nem racionális” tényezőnek, amely vállalkozói cselekvést indukál a beruházás megtétele érdekében (Marchionatti, 1999:431).

Hicks (1931:174) szerint van esély arra, hogy az üzlet teljességgel tönkremegy a benne foglalt és működtetett erőforrásokkal együtt; változó az esélye a kisebb fokú kudarcnak, ugyanakkor mindenféle esélye lehet a sikernek. Az esélyeknek ez a „sémája” függ az alkalmazott termelési technikától, a működés méreteitől, s bár valószínütlen, hogy ezeket a bennük foglalt kockázat tekintetbevétele alapján választják meg, az ugyanakkor egyértelmü, hogy változtatásukkal az üzlet képes lehet változtatni - bizonyos fokig - a vállalt kockázatot is. Úgy találhatjuk, hogy az üzlet feje hezitál a termelés két módozata között, amelyek közül az egyik hatékonyabb, mint a másik, ám ugyanakkor kockázatosabb is. Előfordulhat, hogy érdemes lemondani valamennyi hatékonyságról a nagyobb biztonság érdekében. 
Megfigyelhető, hogy Hicks cikkében a kockázatok „csökkentéséről” értekezik, nem úgy, mint helyenként Knight, aki a kockázat eliminálásáról írt. Knight „mérhető kockázat” doktrínája tanításának az a része volt, amelyet Hicks nem tudott elfogadni annak semmilyen - kompromisszumok nélküli - formájában úgy, ahogy azt Knight először megállapította (Knight, 1921:43).5

A viselkedési közgazdaságtan gondolkodóinak véleménye nyomán vált elfogadottá, hogy fordított kapcsolat van az érzékelt kockázat és a vélt előny között, s a reláció kötődik az egyénnek a hazardírozásra vonatkozó, átfogó értékeléséhez. Ha egy tevékenységet az emberek szeretnek, akkor hajlamosak az előnyeit magasnak, kockázatát viszont alacsonynak ítélni. Ha pedig a tevékenységet nem szeretik, akkor az ítélet éppen fordított lesz: az előnyöket csekélynek, a kockázatot magasnak érzékelnék (Kahneman-Tversky, 1979).

Amennyiben a dolog pozitív fényben jelenik meg a bevezetésnek köszönhetően, akkor valószínűbb, hogy az egyének megmaradnak a döntés pozitív aspektusánál, és vice versa. Bizonyíték van arra, hogy még a szakértők sem immunisak a keretezési hatással szemben. Ugyancsak a kockázatinformációnak logikailag ekvivalens, ám mégis különböző összegzési módjai eltérő értéshez és különböző döntési preferenciákhoz vezetnek (Tversky-Kahneman, 1981; Rabin-Thaler, 2001; Kovács, 2020).

Liles (1974) arra jutott, hogy a vállalkozóvá válással az egyén kockáztatja pénzügyi jólétét, karrierlehetőségeit, családi kapcsolatait és lelki harmóniáját. Azok a személyes pénzügyi kötelezettségek, amelyeket a vállalkozó előidéz sikertelen vállalkozásával, nagyobb veszteséget okoznak a vállalkozónak, mint az egyén számára, tönkretéve nemcsak saját jövőbeni életnívóját, hanem üzleti perspektíváját is. Továbbá, mivel a vállalkozó feltehetően személyes értelemben a vállalatnak szenteli magát, ezért a vállalkozó kudarca valójában az egyén sikertelenségévé válik, s így annak fontos racionális konzekvenciái lehetnek. Felismerve, hogy a kudarc pénzügyi és emocionális konzekvenciái romboló hatást is gyakorolhatnak, Liles azt

5 Érdemes rövid megjegyzést tenni Hicksnek a KNIGHT véleményére vonatkozó kritikájával kapcsolatban. Knight (1921:43) az idézett passzusban a kockázat eliminálhatóságáról egyetlen összefüggésben, a biztosítható kockázat kapcsán értekezik, ebben a formában: „Megengedhető, hogy a vállalkozó bizonyos esetben - fix költség fejében - megszabadulhat a kockázattól, biztosítás révén. Ám a biztosítási aktussal a vállalkozó több mindenről lemond üzletével kapcsolatban: annak kinyilvánításával, hogy a vállalkozó eliminálhatja az összes kockázatot a biztosítás segítségével, nem marad neki jövedelme olyan célok megoldására, mint a menedzsment bére és a monopolprofit. Abban a mértékben, amennyiben az üzletember biztosítást köt, korlátozza szokásos funkcióinak gyakorlását, $\mathrm{s}$ a kockázatot csupán áttestálja a biztosítóra, aki annak elfogadásával maga is vállalkozóvá válik, s egy meghatározatlan maradék vagy profit várományosává lesz. A biztosító jutalma nem az általa kapott prémium lesz, hanem az a különbség, ami a prémium és az általa elszenvedett veszteség között van”. 
javasolja, hogy a potenciális vállalkozó számára tanácsos gondosan analizálni a specifikus üzleti javaslataihoz kötődő kockázatokat, s utána eldönteni, hogy hajlandó-e az üzletet végrehajtani vagy sem.

Liles arra a következtetésre jutott, hogy a döntés nagymértékben attól függ, hogy a potenciális vállalkozónak milyen percepciói vannak a vállalkozásban foglalt kockázatról. A vállalkozói irodalom Mill (1878) írása óta magában foglalja a kockázatviselést mint fö megkülönböztető karakterisztikát a menedzserek és a vállalkozók funkciói között. Brockhaus (1980:513) szerint a vállalkozói kockázat három komponensre bontható: a potenciális vállalkozó általános kockázatvállalási hajlandósága, a kudarc várható konzekvenciái és a kudarc érzékelt valószínűsége egy specifikus vállalkozóra vonatkozóan. A kockázatvállalási hajlandóság a jutalom megszerzésének várható valószínűségeként definiálható, ami a tervezett szituációhoz - annak sikeréhez - kapcsolódik, ami az egyén által elvárt jutalom, mielőtt alávetné magát a vállalkozáshoz kapcsolódó kudarc konzekvenciáinak. Az alternatív szituáció kevesebb jutalmat szolgáltat, s ugyanígy kevesebb hátrányos konzekvenciával jár, mint a tervezett szituáció. Az ilyen definíció lehetne ama helyzet legjobb leírása, amellyel a potenciális vállalkozó szembesül, amikor dönt új üzleti vállalkozás létrehozásáról.

Keynes (1936) - alapozva a piacok és az üzleti pszichológia megfigyeléseire - a kapitalizmus két fázisát tekintette. Az egyik a régi vágású kapitalizmus, ahol

„olyan vállalatok vannak, amelyeket tulajdonosaik működtettek, vagy azok barátai és társai” (Keynes, 1936:150),

azaz ahol nem volt elválasztva egymástól a tulajdonlás és a vállalat menedzselése: „a beruházási döntések a professzionális vállalkozó valódi várakozásaitól függnek; e vállalkozók szangvinikus és temperamentumos egyének, akik konstruktív impulzusokkal felruházva az üzlethez életmódként kezdenek hozzá, s valójában a profit-kilátás precíz kalkulációjára támaszkodnak” (Keynes, 1936:150).

Így a vállalkozói tevékenység sajátos keverékü karakterként feltételezhető, amely emlékeztet

„a tudás és esély kevert játékára, ahol a beruházás nem csupán hideg kalkuláció eredménye, hanem kísértés az esély kihasználására” (Keynes, 1936: 150).

A másik az érett kapitalizmus, amelyben elválik egymástól a vállalat tulajdonlása és menedzselése, ahol a szervezett befektetési piac $s$ a beruházásokról hozott döntés lényegében a részvénypiaci befektetők várakozásától függ. Marchionetti (1999:420) emlékeztet Keynes (1937) véleményére a tekintetben, hogy „szervezett piacokon a befektetések értéke mások megítélésétől függ” (1937:213).

A kockázatvállalás elméleti alapjainak vizsgálatakor megkerülhetetlen az a kérdés, hogy van-e kapcsolat a kamat, a türelmetlenség és a kockázatvállalási hajlan- 
dóság között; s a kérdés szorosan összefügg a kockázat számszerüsíthetőségével. E probléma vizsgálatának korai története arra konkludál, amit Irving Fisher (1930) alapmunkája mutat be, amelyben a nagy gondolkodónak a kockázat számszerüsítésével kapcsolatos álláspontja egyértelmü:

„Amíg lehetséges a kockázat bizonyos típusainak matematikai kiszámítása - mint például az esélyjátékok esetében (klasszikus valószínűség), vagy az élet- és vagyonbiztonság példájában ( relatív gyakoriságon alapuló valószínüség) - addig a közgazdasági kockázatok többsége nem mérhető könnyen. A matematikai formalizálásra tett kísérlet (használható és komplett módon) a kamatráta meghatározására - az esélyek ingadozása mellett - hasonló kísérlet lenne, ha kompletten kifejeznénk - törvényszerüségként - egy olyan projekt pályáját, amelyet a véletlen szélroham befolyásol. Az ilyen formulák szükségszerüen vagy túl általánosak vagy túl empirikusak lennének a komoly érték hordozása reményében" (Fisher, 1930:316).

Ennek alapján mondhatjuk, hogy Fisher elutasította a kockázat valószínűségi mértékét. Az ő alapja a konklúzióhoz kevésbé volt specifikált, mint Knight esetében, ám üzenete ugyanaz volt, mint a jól ismert referenciaosztályoké és a nagy számok törvényéé.

A kockázat számszerűsíthetősége mellett hasonlóan nyitott kérdés a türelmetlenség és a kockázatvállalás közötti kapcsolat, amelynek mélységeit kevéssé tárta fel az irodalom. Az időpreferencia Fisher (1930) kamatelméletének kulcsfogalma. Fishernek megfelelő az időpreferencia vagy türelmetlenség pszichológiai konstrukció, amely vagy azt fejezi ki, hogy a mai javakat preferálja a jövőbeniekkel szemben, vagy a jövőbenieket a jelenlegiekkel szemben, vagy egyáltalán nincs preferencia. Balgah-Buchenrieder (2012:33) hívja fel a figyelmet arra, hogy Fisher összekapcsolja a türelmetlenséget a kockázatvállalással:

„A türelmetlenség foka az azonnali egy dollár százalékos preferenciája az ugyancsak biztonságos (mondjuk egy év múlva esedékes) jövőbeni egy dollár fölött akkor is, ha az összes jövedelem - az egy dollár kivételével - bizonytalan. A jövedelemre vonatkozó türelmetlenség függ a reáljövedelem-áram nagyságától, annak várható időbeni eloszlásától, annak összetételétől, a kockázat és bizonytalanság fokától” (Fisher, 1930:71).

Mivel a jövedelemnek egyaránt van pszichikai és fizikai dimenziója, így a jelenbeli és jövőbeni javak közötti átváltás (azaz a kamatráta) - a konvencionális árelmélettel összhangban - szükségképpen függ a pszichológiai vagy szubjektív komponens komparatív marginális vonzóképességétől. Ennek illusztrálására Fisher (1930:72) a következőket írja:

„Általában - minden egyéb tényezőt változatlannak tekintve - minél kisebb a jövedelem, annál erősebb a jelen preferálása a jövőbeni jövedelemmel szem- 
ben (és) annál nagyobb a türelmetlenség, hogy megszerezzék a jövedelmet, amilyen hamar csak lehet."

Eszerint a kockázatvállalás viszonylatában szükség van nagyobb jövedelemre, mivel a vagyon várhatóan negatívan korrelál a kockázatvállalással, ami a kockázati tartózkodás erősödését jelenti.

Általában a kockázat két dimenzióját szokták azonosítani: az objektív és szubjektív kockázatot. Az objektív kockázat esetében a kockázatok becslése a múltbeli és a valószínü jövőbeni bekövetkezések kvantitatív mérése alapján történik. Másik oldalról a szubjektív vagy érzékelt kockázat az a mód, ahogyan a döntéshozók anticipálják a jövőbeni eseményeket, múltbeli történések ismeretében (Slovic, 1992; Balgah, 2011). A bizonytalanság a kockázat szubjektívebb aspektusainak kifejezésére szolgál, amelyek nem kvantifikálhatók. Fisher gondolkodása alapján mind a kockázat, mind a bizonytalanság, azaz az objektív és szubjektív tényező is befolyásolja a döntéshozatalt.

A Fisher által vizsgált türelmetlenséget - kritikus tényezőként - egyaránt befolyásolja a kockázat és bizonytalanság. Fisher arra a szintre célzott, amelynél az anticipált jövedelem bizonytalansága befolyásolja a mai és jövőbeni többletek relatív értékelését, ahol mindkét növekmény meghatározható és bizonyos. Ezért a kockázat befolyása a türelmetlenségre korlátozott arra a jövőre nézve, amire a kockázat vonatkozik. Amennyiben a jövő kockázatmentes, akkor a szereplők nagyobb valószínűséggel lesznek türelmesebbek. Másik oldalról, amikor a jövő elégségesen nem számol a kockázattal és bizonytalansággal (többek között a háborúkkal és természeti-egészségügyi sokkokkal), akkor a türelmetlenség fokozódik. Fisher erre így utal:

„....amíg a jövő szerencsejáték, addig azok az egyének, akik szeretnek nagy spekulatív esélyt megjátszani, valószínűleg lemaradnak túlzó várakozásaik egy részéről abból a célból, hogy mai jövedelmükhöz viszonylag kis növekményt tegyenek hozzá. Más szavakkal: magas fokú lesz a türelmetlenségük. Ellenkezőleg a szereplők olyan jövedelmet kapnak minden időperiódusban, amely inkább alacsony, mint hogy maga sfokú türelmetlenséget (mutathatna)" (Fisher, 1930:79).

Balgah-Buchenrieder (2012:34) kiemeli Fisher megállapítását, hogy a jövőbeni jövedelem mindig ki van téve bizonyos fokú bizonytalanságnak, ami viszont befolyásolja a türelmetlenség fokát. A kockázat szintjét a jövő determinálja, amelyre a kockázat vonatkozik. Ha az intézményi keretfeltétel garantálja a bárhogyan definiált jövő minimális biztonságát és bizonyosságát, akkor a jövőbeni bőség bizonyossága csökkentheti a türelmetlenség aktuális fokát.

Meglepő párhuzamok demonstrálhatók a megfigyelt kockázati tolerancia érzékenysége és a késleltetési idő iránti megfigyelt türelem, s ugyanígy az értékelé- 
si idő között. A kifizetések halasztása a távoli jövőbe történetesen az embereket egyszerre teszi toleránsabbá a kockázat iránt, egyben türelmesebbé is, s az egyszeri értékelésnek kedvezőbb hatása lesz a kockázatvállalásra, s ugyanígy az idődiszkontálási magatartásra is. Epper-Fehr-Duda (2018:6) joggal teszi fel a kérdést, hogy mivel a hatások nem olyannak tünnek, mint amelyek önkényes rendellenességek lennének a létező modellek elörejelzéseihez viszonyítva, vajon van-e egy olyan közös irányító mechanizmus, amely nem csupán a késleltetést és a folyamatfüggőséget kormányozza, hanem az időzítést, a kockázatot és más függőségeket is. A szerzők e kérdésre igennel válaszolnak.

A tulajdonlás-menedzselés reláció két típusának együttélése, amelyre Keynes utal, az üzleti aktivitást a vállalkozás, a részvénypiaci értékelés és a spekuláció keverékévé teszi. A vállalkozás, amíg lehetséges, hiteles kalkuláción alapul, megtámogatva különös „életfelfogással”, „spontán optimizmussal”, kísértéssel és megelégedettséggel teremtve esélyt az „animal spirits” segítségével. A beruházási tevékenység viszont alapvetően a hagyományos ítéletek irányítják. Eszerint átfogóan az üzleti magatartás a hiteles kalkuláció, a konvencionális ítélet és az animal spirits keverékévé válik. Az üzletemberek motívumait a „szokás, az ösztön, a preferencia, a kívánság és a szándék határozza meg" (Keynes, 1979:294). Ugyanakkor mind a folyamatos üzleti müködésben, mind a beruházási döntésekben tartós tendencia a kockázatvállalás, a kockázatviselés és a kockázatért vállalt felelösség egységének megörzésére.

\subsection{Kísérlet az animal spirits kockázatvállalási szándékként történő újraértelmezésére}

Keynes (1936) alapmüvének 12. fejezetében azt írja, hogy a beruházásokra vonatkozó, hosszú távú vállalkozói várakozásokat a valódi bizonytalanság körülményei között nem kizárólag a hideg számítás határozza meg. Ehelyett a jövőbeni cselekvésre vonatkozó döntéshozatalt befolyásolja az animal spirits - spontán optimizmus vagy sürgetés a cselekvésre -, valamint az olyan nem racionális motívu- 
mok, mint a szokás, hajlam, preferencia, kívánság, akarat és szenvedély, amelyek kiegészítői, sőt helyettesítői a hasznok valószínüségi kalkulációjának. ${ }^{6}{ }^{7}$

Fontana-Marchionatti (2007:1) úgy véli, hogy ezt a nézetet igen kevéssé osztották a közgazdaságtan Keynes utáni gondolkodói. Egyik oldalról úgy értelmezték, hogy az irracionális és pszichológiai motívumok kívül esnek a közgazdasági elmélet tárgyán. Másik oldalról, ha belefoglalták volna azokat a közgazdasági analízisbe, akkor a hosszú távú várakozásokat exogén tényezőként kellett volna tekinteni, olyannak, mint amely teljességgel tetszőleges befolyással van a gazdasági magatartásra. ${ }^{8}$

Az a fogalom megjelenése óta ${ }^{9}$ egyértelmű volt, hogy az animal spirits olyan jelenség, amely teljességgel nem analizálható gazdasági kategóriákkal, s annak pozitív teóriája sem fogalmazódott meg. Dow-Dow (2011:1) azt állítja, hogy az animal spirits kritikus fontosságú eleme volt a bizonytalanság melletti döntéshozatal ke-

6 Az animal spirits hosszú időn keresztül a mellőzött fogalmak kategóriájába tartozott, s lényegében kizárták a tudományos megfontolásból. Ez így volt a keynesiánus közgazdászok többségének körében is, kivéve a posztkeynesiánus szerzők munkáit: JoAn RoBinson (1962) az animal spiritsre funkcionális fogalomként tekintett; George Shackle (1967) és Paul Davidson (1991) a beruházási döntés lényegi irracionalitásának bizonyítékaként hangsúlyozta az animal spirits szerepét.

7 SAKAI (2018) úgy tartja, hogy Keynes elsőként alkalmazta az animal spirits kifejezést, és elemezte annak közgazdasági konzekvenciáit. Keynes véleményéből azt emeli ki, hogy fontos különbséget tenni a spekulációnak tulajdonítható instabilitás és az emberi természetből vagy a spontán optimizmusból származó instabilitás között. Míg az előző matematikai várakozásokhoz kötődik vagy számszerủ valószínűségekhez, addig az utóbbi a valódi bizonytalansághoz kapcsolódik, ami nem mérhető és nem összehasonlítható.

8 Az utóbbi időben az animal spirits nagy figyelmet kapott AKERLOF-SHILLER (2009) könyvének megjelenésével. A szerzők a következőket írják az előszóban: „A gazdaság megértéséhez azt kell megtudni hogy azt miként mozgatja az animal spirits. Amint Adam Smith számára a láthatatlan kéz a klasszikus közgazdaságtan kulcsfogalma, addig Keynes számára az animal spirits a kulcsszó a gazdaság egy másik szempontjából - egy olyan nézet, amely magyarázza a kapitalizmus alapvető instabilitását" (AKerlof-Shiller, 2009, Preface:IX).

Dow-Dow (2011) szerint a kontextus, amiben a szerzők megközelítették ezt a koncepciót, az a viselkedési közgazdaságtan volt, amely felhasználja a pszichológiai elméletet és az idegtudományt, hogy segítsenek a közgazdászoknak megérteni a kísérleti szituációkban megfigyelt aktuális magatartást. Különösen azt a vonatkozást megérteni és előrejelezni azt a magatartást, ami kihívásnak látszik ama modellek predikcióival szemben, amelyek a racionális egyéni magatartás axiómáira épülnek.

9 Mattews (1984:212) megjegyzi, hogy az animal spirits már Hume (1739:318-319) Human Nature művében megjelenik az „én animal spirits irányultságom és szenvedélyem” formában. 
retfeltételeinek, amely - szélesebb értelemben - racionális és elfogadható argumentum volt. ${ }^{10} / 11$

Az animal spirits Keynest követö felfogásának megértéséhez érdemes felidézni az eredeti szándékot. Keynes (1936) a kategóriát három alkalommal használja müve 161-163. oldalán, ahol a vállalkozók reáltőke-beruházási döntéseivel foglalkozott:

„Valószínủleg döntéseink többsége valami pozitív tettre irányul, ahol a döntések konzekvenciája sok idő eltelte után derül ki, s csupán az animal spirits eredményeként tekinthetők - ami spontán sürgetés a cselekvésre inkább, mint a nem cselekvésre, s nem a kvantitatív előnyök súlyozott átlagának és a kvantitatív valószínüségeknek a szorzata. (...) Így ha az animal spirits elhomályosul és a spontán optimizmus botladozik, akkor semmi mástól nem függhetünk, csak a matematikai várakozásoktól, s a vállalat lehervad és megszünik - a veszteségtől való félelem alapja lehet annak az érzületnek, hogy a profit nem lesz annyi, mint korábban. Ámbár az egyéni kezdeményezés megfelelő lehet, amikor a megbízható kalkulációt kiegészíti és támogatja az animal spirits úgy, hogy a végső veszteség gondolata utoléri a pionírokat, ahogy ezt a tapasztalatok kétségtelenül mutatják" (1936:161-163).

A közgazdasági irodalom az animal spiritsre reziduális tényezőként tekint, amely szükségképpen magában foglal irracionalitást és véletlenszerüséget. FontanaMarchionatti (2007:3) úgy látja, hogy a Keynes gondolatában szereplő „spontán sürgetés a cselekvésre a nem cselekvés helyett” két komponensre bontható. Az elsőnek általános hatása van, mivel befolyásolja az összes gazdasági szereplő magatartását. A jelenlegi és jövőbeni kilátások interpretációját időnként kondicionálják (Keynes szavaival): „az irracionális pszichológia és az emóciók hullámai, amelyek függnek az idegektől és a hisztériától”. Definíció szerint az animal spirits e része kitér a szisztematikus kezelés elől. A második - a spontán optimizmus - kapcsolódik a vállalkozók ama vonásaihoz, amelyeket a marshalli és a schumpeteri tradíció reprezentál. Keynes szavaival: „szangvinikus temperamentumú egyének és konstruktív impulzusok jelennek meg az üzletben életmódként”. A spontán optimizmus az a jellemzö, amely megkülönbözteti a vállalkozókat a többi gazdasági szereplőtől: ezek hajlandósága kockázatos tevékenység folytatására nem

10 Az Oxford English Dictionary az „Animal spirits” szócikkben a következő megfogalmazásokat közli: (i) a feltételezett „szellem” vagy az érzékelés és az önkéntes mozgás alapelve, válaszolva az idegváltozékonyságra, az idegi erőre és az ideges cselekvésre; (ii) idegi, fizikai vagy „animal” bátorság; (iii) ideges élénkség, természetes hajlam a vidámságra, egészséges „animalizmus”.

$11 \mathrm{Az}$ animal spirits jelentését elemző irodalomban egy időben vita folyt arról, hogy Keynes a jelenség felvetésekor támaszkodhatott-e Descartes e tárgyban tett megjegyzéseire. A formális citátum hiányában a KoPPL (1991), és MogridDGE (1992) közötti vita eldöntetlen maradt. A fogalom által sugallt szellem nem zárja ki, hogy Keynes Descartes-ra támaszkodott. 
csupán a költségek és hasznok egyenlegétöl függ, hanem természetes hajlandóság arra, hogy elkötelezödjön a vállalat iránt, amelynek müködési kimenete bizonytalan. Ez a természetes hajlam a befektetés kockázatának viselésére - hosszabb távon - fontos szerepet játszik a beruházások szintjének fenntartásában, valamint a korlátozott információk és a bizonytalanság negatív hatásainak ellentételezésében. Ez az animal spirits olyan aspektusa, amelyre felépíthető az animal spirits pozitív teóriája.

Keynes analízisében az animal spirits alapvetően a vállalkozói magatartáshoz kapcsolódik. A vállalkozás szerepe, s így az animal spirits hatásterülete megváltozott a termelő és szolgáltató szektorban bekövetkezett strukturális változások hatására. Gerrard (1994:16) utal arra, hogy a vállalatok tulajdonos általi menedzselésének relatív visszaszorulása az üzleti életvitel súlyának mérséklődésével járt. Bár Keynes tőkeberuházási analízisét az egyéni tulajdonos-menedzser vállalkozóra valamint a pénzügyi piacok szerepére fókuszálta, az elméleti alap az agresszív vállalkozói magatartás, s benne az animal spirits maradt (Keynes, 1936:12. f.). Ez a vállalatoknak a részvénytőke-finanszírozástól való függőségéből eredt, amikor a tulajdonos által irányított vállalatokból nyilvánosan jegyzett korporációk lettek. A beruházási tervek pénzügyi piacok általi értékelése ezért korlátot emelt a vállalkozói aktivitás elé,még a nagyobb vállalatok esetében is.

Dow-Dow (2011:11) szerint a nyilvánosan jegyzett vállalatban a menedzserek morális felelőssége, hogy érvényesítsék a részvénytulajdonosok érdekeit, s elkerüljék a túlzott kockázatvállalást. Így a morális érzékenység vesztesége az üzleti magatartásban a közbeszéd kurrens vonásává válik, különösen amiatt, mert az elv megsértésére az utóbbi évtizedek számos példát szolgáltattak.

A tulajdonlás és müködtetés kettéválására azért kell súlyt helyezni, mert Keynes szerint az animal spirits azon vállalkozók veleszületett kapacitására vagy ösztönére/hajlamára utal, akik „régimódi kapitalizmussal” jellemezhetők. Keynes megfogalmazásában: ezek a szangvinikus temperamentum egyénei, akik az üzletbe életformaként vágnak bele" (Keynes, 1936:150). Ő azt is explicitté tette ezekben a passzusokban, hogy az animal spirits nélkül a beruházások elégtelenek volnának. Annak az oka, hogy a beruházási döntés az animal spiritsre támaszkodik, az, hogy a racionális kvantitatív kalkuláció egyedül nem képes igazolni a bizonytalanság melletti cselekvést.

Marchionatti (1999:430) érdeme az a felismerés, hogy ha találunk gazdasági tényezőket, amelyek szisztematikusan befolyásolják az animal spirits létezését, akkor mondhatnánk, hogy annak az analízise a közgazdasági elméleten belül történhet, és ezt követően elutasithatnánk a teljes önkényesség állitólagos karakterisztikáját, ami sok gondolkodót az animal spirits elutasitására indított. 
Ennek esélyt ad, hogy Keynes (1936) alapműve - szellemét tekintve - lehetővé teszi az animal spirits szélesebb interpretációját. Keynes a gazdaságot nyitott, organikus rendszernek tekinti, ahol a kreativitás és az evolúciós változás azt jelentette, hogy a múltnak csupán korlátozott iránymutatása van a jövőre vonatkozóan. Schakle (1972) szerint a kreatív magatartás és a társadalmi struktúrák változása oly módon megy végbe, ami nem előre jelezhető kvantitatív valószínűségek bázisán. Az intézmények és a kialakuló társadalmi gyakorlat stabilabb környezetet szolgáltat a döntéshozatalhoz, ám ahogy Keynes (1937:214) hangsúlyozza, az okot és bizonyítékot ki kell egészíteni a (bizonytalan) tudás más formáival: a konvencionális tudással, a szakértők ismereteivel és a múltbeli tapasztalatokra támaszkodással. Keynes (1936) a fentebb idézetteken túl a következőket írta az animal spiritsről:

„A jövőt befolyásoló emberi döntések, legyenek azok személyesek, politikaiak vagy gazdaságiak, nem függhetnek szigorú matematikai várakozásoktól, mivel az ilyen kalkulációnak nincsenek meg az alapjai (...) ez a mi velünk született sürgetésünk a cselekvésre, ez mozgatja a kerekeket, racionális énünk választja azt az alternatívát, amire a leginkább képesek vagyunk, ott végzünk kalkulációt ahol tudunk, ám gyakran visszahullunk a szeszély, az érzelem vagy az esély szintjére" (1936:162-163).

Keynes analízise azt jelzi, hogy az animal spirits relatív fontossága veleszületett hajlamként nagyobb egyeseknél, mint másoknál bizonyos körülmények között, s ezért helyezte a diszkusszió fókuszába e kategóriát a vállalkozói cselekvés vizsgálatakor.

Marchionatti (1999:430-431) fontos felismerése, hogy a magatartásnak az animal spiritset követő vállalkozói választása teljességgel nem tekinthető nem gazdasági (vagy irracionális) döntésnek, hanem inkább olyannak, ami politikai, társadalmi vagy gazdasági atmoszférára utalással magyarázható. Ez a kontextus a három szféra szabályaira utal és olyan intézményi környezetet is idéz, amely kedvező a vállalkozók számára: az ebben bekövetkező változások pszichológiai reakciókat indukálnak, s magyarázzák is az animal spirits és a várakozások hirtelen változásait. Az atmoszféra gazdasági jelentése elemezhető szervezeti és környezeti tényezők halmazára utal a közgazdaságtan és az innováció területén kidolgozott koncepciók segítségével, mint például a vállalat életkora és a verseny intenzitása.

Abban is egyet kell érteni Marchionatti (1999:434-435) felvetésével, hogy Keynesnek a bizonytalanság melletti gazdasági magatartásról írt analízise általános modellként tekinthető, amely tartalmazhat arra vonatkozó bizonyítékot, hogy a szereplők megkísérelnek racionálisak lenni mind magatartásukban, mind a hosszú távú várakozások formálásában. Ebben a kontextusban az animal spirits olyan jelenség, amely a tradicionális elvek szerint valóban nem tekinthetö a közgazdasági elmélet részének, ám analizálható az intézményi és a gazdasági atmoszférára 
utalással. Az első ama pszichológiai reakciók alapján elemezhető, amelyeket az intézményi kontextus változásai indukálnak; az utóbbi annak az innovatív magatartásnak a motivációjára vonatkozik, amely tényezőként befolyásolja a hosszú távú gazdasági haladást.

Keynes fontosnak tartotta értékelni a konvenciók szerepét az animal spirits kontextusában is, amikor a következőket írta:

„...ha támaszkodhatunk a konvenció fenntartására, akkor egy befektető jogosan felvértezheti magát azzal az ideával, hogy csupán a kockázat idézhet elő igazi változást a közeljövő újdonságaiban, amelynek nem túl nagy valószínűsége megkísérelheti formálni saját ítéletét. Feltételezve, hogy a konvenciót jónak tartják, csupán ezek azok a változások, amelyek befolyásolhatják a befektetés értékét, $s$ nem veszíthetik el a reményt csupán azért, mert semmit nem tudnak a befektetés tíz év múlva várható értékéről. Így a befektetés hitelesen »biztonságossá« válik az egyéni befektető számára rövid periódusra, akár többre is, ha képes méltányosan támaszkodni a zavarok nélküli konvenciókra, s van lehetősége ítéletei korrigálására és befektetése megváltoztatására, mielőtt sok minden történhetne. Azok a befektetések, amelyek »fixek« a közösség számára, azok likviddé tehetők az egyének számára” (Keynes, 1936:152-153).

Keynes szerint a konvencionális ítélet és az animal spirits együtt a bizonytalanság arányának determinánsaként interpretálható, vagy a megbízható kalkuláció hitelesítőjeként, amikor a bizalom alacsony (1936:152-153). Gerrard (1995:191) megközelítése szerint az animal spirits - legalábbis részben - úgy tekinthető, mint ami a bizalom állapotának determinánsa; a bizalom önmagában „a rendelkezésre álló súly, s a hiba kockázataként értékelhető" (uo. 191).

Dow-Dow (2011:7) igazolja, hogy az animal spirits koncepció Keynes általi használata túlmegy a „vállalkozó állandó jellemzője” felfogáson, s megengedi a spontán optimizmus „botladozását”. Ha a bizonytalanság a várakozások iránti bizalom csökkenése miatt növekszik, akkor az elriaszt az aktív döntéstől. Dow-Dow (2011:8) kiemeli, hogy a bizalom foka fokozatokkal változhat; ugyanígy az animal spirits is értelmezhető úgy, mint ami fokozatokkal változik. Így míg a beruházási döntés kezelhető a cselekvés/nem cselekvés kétosztatú koncepciójaként, addig az animal spirits szélesebb alkalmazása megengedné a cselekvés fokozatait, kiindulva a likviditási preferenciától a konvencionális ítélet különböző fokain keresztül a tiszta kreatív innovációig.

Mindaddig, amíg várakozásokról van szó, addig az erős animal spirits a spontán optimizmus formáját ölti, olyan optimizmusét, amely logikailag nem következik az okból és a bizonyítékból. Egészen addig, amíg a várakozásokkal kapcsolatos bizalomról van szó, addig az erős animal spiritsnek két formája van: egyik oldalról a bizonytalanság csekély súlyúnak ítélése, másik oldalról pedig fokozott 
hajlandóság a cselekvésre annak ellenére, hogy bármilyen bizonytalanság érzékelhető lenne. Mindkettő ki van téve a körülményektől függő változékonyságnak. Ez magában foglalja azt, hogy létezhetnek olyan strukturális tényezők, amelyek ösztönzik a vállalkozókat, s így erösítik az animal spiritset, elválasztva a körülményektől.

Mindezek alapján az animal spirits az a közbülső láncszem, amely összekapcsolja az ok és a bizonyiték indítékát a valós kockázatvállalást jelentő döntéssel. Az animal spirits jelenti a végső lökést elöidézö áttörést, s mint ilyen, a kockázat vállalását jelentő mozzanatot. Az animal spirits a spontán optimizmusra támaszkodva alkalmas a bizonytalanság (mint cselekvési korlát) érzékelésére és ignorálására, valamint fokozott cselekvési hajlandóságra. Ezért az animal spirits kapcsolódik ahhoz a bizonytalan tudáshoz, amelyen a döntések alapulnak, s ahol a változásokkal kapcsolatos bizalom függ a bizonytalanság felismerésének hajlandóságától. Úgy, ahogyan a gondolkodás és az emóció kölcsönkapcsolatban van egymással, ugyanígy az animal spirits is kötődik a döntéshozatal más inputjaihoz. Míg a konvenciók és a rutinok a bizonytalanság elkerülésének passzív útját jelentik, addig az animal spirits gyakorlása az elkerülés aktív útja. Ebből következően feltárhatók az interakciók az animal spirits és a döntéshozatal egyéb hozzájárulói között.

Dequech (1999:420) az animal spiritset úgy vezeti elő, mint „optimista hajlamot” a bizonytalansággal szembesülésre. $\mathrm{Ha}$ az animal spirits erős abban az időben, amikor a cselekvést nem támogatja az indíték és a bizonyíték, akkor az animal spirits - egy bizonyos ponton - áttörést okoz. Dequech (2011:18) véleménye másutt nagyon frappáns, amikor azt írja, hogy az animal spirits a tudatalattiban van, sem nem véletlenszerü, sem alávetve nincs a teljes magyarázat kényszerének: az sem racionális, sem irracionális, hanem inkább aracionális, azaz a racionalitást nem mérlegelö indulat, az értelem helyett az érzelem tartományába tartozik.

\subsection{A racionális választás a kockázat és bizonytalanság körülményei között - a keynesi példa}

A huszadik század első felében a racionális választás teóriája a neoklasszikus közgazdaságtan központi elemévé vált. Ahogy ezt Schirillo (2017:77) leírja, a döntéshozatal elméletének kifejlődésére „pszichológiaellenes” fejleményként tekintették. Az új elméleti keretfeltételt úgy hozták létre, hogy a racionális választás folyamatát analitikus folyamatokkal és matematikai korlátokkal megfosztották mindenféle pszichológiai és leíró tartalomtól. A racionalitás a preferenciák vagy a választás konzisztenciája alapján konstruálódott, így az egyén akkor racionális, ha koherens módon viselkedik, és konzisztensek a preferenciái. Más szavakkal, az egyén akkor racionális, ha képes világos gondolkodásra, továbbá képes olyan 
döntések meghozatalára és olyan itéletek alkotására, amelyek okságon alapulnak. Következésképpen történt egy világos elválasztás a közgazdaságtan és a pszichológia között. Míg az előbbi a normatív elméletek centrumához került (miként kell az egyénnek cselekednie), az utóbbi viszont az aktuális viselkedés tanulmányozásának területévé vált.

A kockázat és bizonytalanság melletti racionális választás a valószínűség fogalmára alapozódott. Eszmetörténeti tény, hogy a valószínűségi elmélet a kockázat racionális megközelítéseként fejlődött ki, s e terület gondolkodói burkoltan feltételezték, hogy az egyénnek meg kell engedni: ha kockázatos döntés elött áll, akkor racionálisan viselkedjen. ${ }^{12}$

A befektetők mindig a kedvező megtérülés elérésére törekszenek, ezért tendenciaszerűen olyan beruházási döntéseket hoznak, amelyek várhatóan nyereséget biztosítanak. Ez elvileg anélkül lehetséges, hogy tekintettel lennének az adott vállalkozásban foglalt kockázat nagyságára. Chapman (2019:17-18) szerint a befektetők inkább arra teszik tétjüket, amiben biztosak, ahelyett, hogy csupán spekulálnának. A kompetitív környezet a befektetők által realizálható nyerés bizonytalanságát idézi elő. Sok befektető ilyen helyzetben el fog térni attól a racionális magatartástól, amely magas megtérülés elérését tűzi ki célul. A döntéshozatal annak a kulcsa, hogy miként határozódik meg valamely beruházás által elért nyereség nagysága. A részvénypiacok kompetitív környezete szükségessé teszi a befektetői óvatosságot a döntéshozatalban. Ugyanakkor fontos, hogy a racionalitás legyen a fó cél a maximális nyereség elérése érdekében. Ezért mind a racionális, mind az irracionális magatartást tekintetbe kell venni mindaddig, amíg a döntések biztosítják a maximális profitot. Mindezekből világosan érthető, hogy miként határozza meg a kockázat a beruházási döntéseket, amint az erősen befolyásolja a racionalitást.

A racionalitás kritériuma - a neoklasszikus tradícióban - megkövetelte a hasznosság maximalizálását úgy, hogy azt a gazdasági entitást más szereplőkkel összekapcsoló interakciók értékelése nélkül tették, ám Neumann-Morgenstern (1944) átformálta a kritériumot. Roggi-Ottanelli (2013) szerint az a gazdasági entitás, amely maximalizálásra törekszik, a valóságban kapcsolódik egy átfogó stratégiához, amely képes figyelembe venni a más szereplőkkel létrejövő potenciális köl-

12 Marchionatti (1999:416-417) felhívja a figyelmet arra, hogy a neoklasszikus közgazdaságtanban valódi bizonytalansággal szembesülve nincs alap racionális ítélet formálására. A LucAs által hangoztatott idea: „a bizonytalanság eseteiben a közgazdasági megokolásnak csekély értéke van” (Lucas, 1981: 224) domináns nézet az utóbbi évtizedekben. A neoklasszikus „racionális posztulátum" mellett a várakozás-formálás egyetlen kielégítő módja MUTH (1961) racionális várakozások modelljének alkalmazása, ami képessé tesz az endogén várakozások bevezetésére. A racionális várakozások modell azt feltételezi, hogy a várakozások korrekten azonosítják a jövőbeni függőségeket befolyásoló sztochasztikus változók átlagát és varianciáját, s így megoldja a gazdasági szereplők jövőt érintő hibás hitének problémáját. 
csönkapcsolatokat. A játékelmélet diszciplínája a „stratégiai interdependencia” koncepcióján alapul, annak megfelelően, hogy az egyének cselekedeteinek eredményei nagymértékben függnek mások választásától, s ezért az optimum a mások magatartása által befolyásolt érzületek bázisára épül. A játékelmélet kontextusában a kockázat specifikusabb módon (kisebb hatással) jelentkezett, összehasonlítva a tradicionális koncepcióval, amely nem azon egyének cselekedeteinek konzekvenciája volt, akikkel minden egyén kapcsolatba kerülhet.

A fontos döntések magukban foglalnak kockázatot. Így nem meglepő az, ha megkíséreljük megérteni, hogy a döntéshozók miként építik be a kockázatot választásaikba. Természetesen a kockázati tartózkodás mindenkor fontos szerepet játszott a gazdasági problémák megoldásának segítésében olyan különböző területeken, mint a biztosítás, szerződéskötés és portfóliószelekció (Arrow, 1971; GrossmanHart, 1983; Markowitz, 1959). A kockázatos választás modelljeinek esetében, legyenek azok normatívak vagy leírók, feltételezni kell, hogy az egyének úgy értékelik a kockázatos kilátásokat vagy a lottó játékot, hogy alkalmazzák a súlyozott átlag valamilyen típusát, ezért ki kell egyensúlyozni a viszonylag jó kimeneteket a relatíve gyengébb eredmények lehetőségével (Gneezy -List-Wu, 2006).

A kockázat melletti döntéshozatal klasszikus kezelésében a kiegyensúlyozás formalizáltan megragadható: ebben a kimenet hasznosságát súlyozzák a bekövetkező kimenetek valószínűségével. A kilátáselmélet ugyancsak súlyozottátlag-sémát alkalmaz, ahol a kimenet hasznosságát súlyozzák egy döntési súllyal, amely általában túlsúlyozza a kis valószínüségeket és alulsúlyozza a közepes és nagy valószínűségeket (Kahneman-Tversky, 1979; Tversky-Fox, 1995; Tversky-Kahneman, 1992).

Közismert tapasztalat, hogy nehéz modellezni az egyének döntéshozatalát a kockázat és bizonytalanság körülményei között. Ehelyett létezik egy másik vonulat annak a leírására, hogy az egyének miként hozzák a döntéseket. Ebben az esetben arra fókuszálnak, hogy az egyének miként érzékelik és interpretálják a kockázatot és bizonytalanságot, s hogy milyen hajlamjellemzők befolyásolják választásaikat a kockázat és bizonytalanság körülményei között. Park-Shapira (2017) kiemeli, hogy kísérlet történt olyan kockázati attitüd megfogalmazására, ami stabil egyéni jellemző, s ami a személyiséghez és kultúrához kötődik (vö. Douglas-Wildawsky, 1982). Ám a vélemények közötti konszenzus- és konzisztenciahiány azt üzeni, hogy nincs potenciális kapcsolat a kockázatvállalás és a hajlam jellemzők között (Slovic, 1964). Ezen kívül azonban léteznek a kockázatvállalásra ható, más tényezők is. Az egyének kockázati preferenciája kapcsán például azt találták, hogy az a döntési probléma keretfeltételein fordul meg (Tversky-Kahneman, 1981), valamint az egyének hangulatán és érzésein múlik a döntés pillanatában (Loewenstein et al., 2001). Brockhause (1980:511) meglátása szerint a teljesítményszint akkor lehet a legmagasabb, amikor a legnagyobb a bizonytalanság a kimenet körül (amikor a siker va- 
lószínűsége 0,50). (Ez a megállapítás rezonál Knight korábban vizsgált profitelméletére.) Ez a predikció feltehetően igaz lehet, függetlenül attól, hogy az egyénben a cél elérésének a motívuma az erősebb-e, vagy a kudarckerülésé. Mindazonáltal az az egyén, akiben az elérési motívum az erősebb, az kell, hogy preferálja a közepes kockázatot, s ehelyett preferálni vagy a nagyon alacsony eredményü biztonságos megvalósítást, vagy sokkal erősebb motiváltsággal törekedni a kudarc elkerülésére. Arra is tendálhat, hogy biztonságos feladatot oldjon meg, vagy hogy könnyen magyarázhassa a nagyon spekulatív feladat teljesítésének kudarcát anélkül, hogy felmerülne az egyén hibáztatása.

Fontana-Marchionatti (2007) cikkében hangsúlyozza Keynesnek a várakozásokra vonatkozó egyik alapvető tételét, hogy ti. a hosszú távú várakozások függnek a szereplők által készíthető legvalószínűbb előrejelzéstől és attól a bizalomtól, amellyel ezt az előrejelzést illetik. Mivel a jövő ismerete gyakran „fluktuál, határozatlan és bizonytalan", ezért nem lehetséges felhasználni a várakozások valószínüségi elméletét. Keynes erről a következőket írja:

„Általánosan fogalmazva, döntéshozatalkor változatok sokasága áll előttünk, amelyek közül (...) nincs egy sem, amely racionálisabb lenne a többinél abban az értelemben, hogy sorba rendezhetnénk a módszereket, miként aggregálják a komplett konzekvenciákból nyerhető hasznokat. Hogy elkerülhessük Buridán szamarának helyzetét, s azért, mert oda jutunk és szükségképpen hozzá hasonlóan cselekszünk, s a motívumok olyan típusainak engedelmeskedünk, amelyek a konzekvenciák értékelését illetően nem racionálisak abban az értelemben, hogy a szokás, hajlam, preferencia, kívánság, akarat lesz a döntö" (Keynes, 1979:294).

Mondanivalónk szempontjából alapvetően fontos tény, hogy Keynes elutasitotta az irracionalitás döntő szerepét az emberi magatartás magyarázatában a bizonytalanság körülményei között; ő nyomatékosította, hogy

„... nem konkludálhatunk arra, (...) hogy minden az irracionális pszichológia hullámaitól függ” (Keynes, 1936:162).

Éppen ellenkezőleg: emlékeztetni remélt minket arra, hogy az emberi döntéseknek limitált információs és kognitív bázisa van.

„...az emberi döntések befolyásolják a jövőt ... s azok nem függhetnek szigorú matematikai várakozásoktól, mivel egy ilyen kalkuláció végzésének nincs alapja” (Keynes, 1936: 48)

Keynesnek megfelelően, bizonytalan környezetben indokolt, hogy a gazdasági szereplők döntései függjenek a konvencionális ítéletektől, az animal spiritstől a racionális kalkuláció kiegészítésével és támogatásával. A neoklasszikus közgazdaságtan képviselői bizonyos idő óta elutasítják ezt a tételt olyan feltevéssel, hogy a valódi bizonytalanság esetében a racionalitásnak csekély értéke van, mivel sze- 
rintük a racionalitás birodalmán kívül csak az irracionalitás territóriuma létezik. Ugyanerre a következtetésre jut Marchionatti (1999:434-435).

A probléma az, hogy habár a konvenciók adaptálása adott körülmények között hiteles cselekvési mód a beruházás megtételére, a döntéshozók mégis tudatában vannak annak, hogy

„egy beruházás aktuális eredményei évek hosszú során keresztül ritkán esnek egybe az eredeti várakozásokkal” (Keynes, 1936:152). Mivel ők „nagy változásokat remélnek, ám bizonytalanok abban, hogy e változások pontosan milyen formát öltenek, (...) bizalmuk ebben nagyon kicsi” (Keynes, 1936:148). A döntések előrejelzései, s így a hosszú távú várakozásaik állapota ennek következtében hajlamos hirtelen revízióra a hirtelen bekövetkező változások hatására.

Keynes (1937) cikkében élesen elhatárolódott a klasszikus közgazdaságtan vonatkozó tételétől, amely szorosan kapcsolódott a racionalitásról vallott felfogáshoz:

„Az elméletet, amelyet kigondolunk annak a tanulmányozása során, hogy miként viselkedünk a piacon, önmagában nem kellene alávetni a piaci bálványoknak (amilyen a benthamita kalkulus). Vádolom a klasszikus közgazdaságtan teóriáját, ami önmagában is egyike a bájos, finom technikáknak, amelyek úgy kísérlik meg a jelennel foglalkozást, hogy elvonatkoztatnak ama ténytől, hogy nagyon keveset tudunk a jövőröl” (Keynes, 1937:215).

Ezért nem lehet meglepő, hogy Keynesnél a „racionális magatartás” kezelése közgazdaságtani írásaiban nem a várható hasznosság maximalizálásán alapul. Eltérően a modern közgazdászok többségétől, Keynes a gazdasági motívumra úgy tekintett, mint olyan tényezőre, amelyik egy a sok közül (Bateman, 1988; Lawson, 1986), s továbbá, amelyet hasznosan kiegészít egy olyan „irracionális tényező”, mint az animal spirits, szeszély, hóbort s hasonlók. Keynes analízisét és konklúzióit olyan információk táplálják, amelyeket különös társadalmi és gazdasági kontextus övez, amilyenben a döntéshozók is találják magukat, a különböző időhorizontok implikációi különböző típusú elörejelzésekhez vezetnek, ahogy ezt Runde (1989:289) fogalmazza.

O’Donnell (1990) nyomán árnyaltabb képet kapunk Keynes racionalitáskezeléséről. Ö argumentáltan írja le azt a hangsúlyeltolódást, amely Keynes gondolkodásában végbement a húszas évek közepétől. Anélkül, hogy Keynes (1921) eltávolodott volna valószínűségi müve eszmei alapjától, gondolkodásában megnövekedett a gyenge racionalitás súlya, ellenben mérséklődött az erős racionalitás jelentősége.

O’Donnell (1990:259-260) szerint a gazdasági szereplők racionalitásának vitatott kérdéséhez a kulcsot Keynes (1936) alapvető müvében az a jellemvonás adhatja meg, hogy a mü nem a racionalitás neoklasszikus elméletére alapozódik, hanem a valószínűségi logika és a tiszta pszichológia közötti elméleti alapvetésben gyökerezik, ami Keynes (1921) valószínűségi műve nem neoklasszikus keretfeltételeiből 
származik. Nem meglepő, hogy Keynes racionalitásteóriája nem volt rokonszenves a neoklasszikus elmélet gondolkodói számára. ${ }^{13}$

Keynes haladást ért el azáltal, hogy újító módon felvázolta a racionalitás elméletét a fundamentális bizonytalanság körülményei között, s nyitott volt a fejlődésre a neoklasszikus teóriánál kevésbé korlátozó keretrendszerben. Figyelemre méltó az a mód, ahogyan elutasította a teljes irracionalitást vagy a tiszta pszichológiát, ám kitartott amellett, hogy az extrém bizonytalanság melletti magatartás hozzákapcsolható a racionalitás magvához.

Keynes nézete lényegében az volt, hogy a racionális szereplők a legjobbat teszik, amit adott körülmények között megtehetnek. Amikor úgy helyezkednek el a környezetben, hogy hiteles információkkal nem rendelkezhetnek, s a racionalitás erős formái nem érhetők el, akkor döntési körülményeik besoroltatnak a gyenge racionalitás formái közé, s ez a helyzet pszichológiai motívumokat is tartalmazhat. Jó példa erre Keynes (1937) cikkének összefoglalója. A redukálhatatlan bizonytalanság magyarázata után Keynes áttér a racionalitás és a magatartás vizsgálatára, megállapítva, hogy a racionalitás tradicionálisan destruktív formái mellett

„...úgy menedzseljünk, (...) hogy viselkedésünkkel óvjuk meg arcunkat mint racionális gazdasági emberek" (Keynes, 1937:214).

Mindez azt jelentette, hogy Keynes szembefordulása mindvégig megmaradt ahogy O’Donnell (1990:254) fogalmazta - a mindentudás ultraracionalitása viszonylatában.

\subsection{A kockázat kanonizálásának két útja: a várható hasznosság maximalizálása és a portfólió optimalizálás}

A múlt század húszas-harmincas éveiben - nem kis mértékben Knight (1921) és Keynes (1921), valamint Keynes (1936) alapvető munkája nyomán - a beruházási döntéshozatalban megjelent a kockázat és bizonytalanság megfontolásának szükségessége. A kockázatvállalás elméleti hátterének tisztázása, a racionális választás teóriájának megfogalmazása, a bizonytalanság szerepének minden korábbinál erőteljesebb hangsúlyozása Knight és Keynes által szilárd alapot teremtett a koc-

13 Kritikus jelentőségű megjegyezni, hogy a beruházási döntések a várható megtérülés megfontolása alapján születnek. KAHNEMAN-TversKy (1981) haladást ért el a kockázati tartózkodás elméletében, s ennek eredményeként a döntéshozatalban. Feltevéseiket és javaslataikat „Prospect Theory” című munkájukban összegezték. Ők kihívást intéztek az emberi viselkedés racionalitásával szemben a döntéshozatalban, amikor a döntéshozók ugyanazon probléma eltérő módon történő prezentálásával szembesültek. Az ilyen szituációhoz hasonló esemény során a befektetők hajlamosak olyan vállalkozást választani, amellyel a veszteség elkerülhető a kockázat kerülése helyett. 
kázat és bizonytalanság döntéshozatali funkciójának elfogadásában. A kockázat és bizonytalanság beemelése a közgazdaságtani kánonba két úton - egyrészt a várható hasznosság maximalizálása, másrészt a portfóliódiverzifikáció útján történhetett.

A várható hasznosság alapulvétele a bizonytalanság melletti választáshoz a tizennyolcadik századig nyúlik vissza. A Bernoulli-féle (1738) elméleti vívmánynak két ága volt: az egyik a nagy számok törvénye, a másik a kockázati tartózkodás befoglalása a bizonytalanság közepette történő választási döntésbe. A döntés ilyetén megközelitése közelebb volt a realitáshoz, mint a csupán a várható nyereségre alapozott számítás. A várható hasznosság paradigmája két új dolgot hozott felszínre: az egyik a hasznosság mérésének igénye, a másik az a nehézség, ami a kísérletek többezres ismétlődéséhez kapcsolódik, hogy közelebb jussunk a véletlen változó átlagának becsléséhez.

Bernoulli a várható érték és az egyén fizetési hajlandósága közötti ellentétet úgy vélte feloldani, hogy a megoldásban a kifizetések várható értékét azok várható hasznosságával helyettesítette. A nyeremény pénzértéke helyett annak morális értékét vette alapul. Emiatt az egyén nem kizárólag racionális alapon, hanem egyéni hasznosságérzete alapján, szubjektíven dönthetett a választásról. Bernoulli felismerte, hogy a vagyon pénzegységgel történő, folyamatos növekedése egyre kisebb örömet okoz az egyénnek, mert ezáltal egyre kisebb mértékben javul a jóléte. Ö a vagyon és a hasznosság kapcsolatát a következőképpen fogalmazta meg: „A vagyon növekményének hasznossága fordított arányban lesz a már korábban birtokolt javak mennyiségével” (Bernoulli, 1738; 1954:25). Ez arra utal, hogy Bernoulli feltételezte az egyének kockázatkerülő magatartását, hiszen ezért utasítják el az elvileg végtelen összegü nyereséget kínáló játékot. ${ }^{14}$

Bernoulli szerint egy játékban a nyereség növeli a hasznosságot, ám kisebb mértékben, mint ahogy a veszteség csökkentené azt. Következésképpen a közgazdaságtan sok gondolkodója arra jutott, hogy a kockázatvállalási hajlandóságnak „irracionálisnak” kell lennie, eszerint a kockázat vagy bizonytalanság melletti választást gyanúval fogadták, vagy legalábbis a közgazdasági elmélet birodalmán kívül levőnek tekintették, mert a közgazdaságtan racionális szereplöket feltételezett.

14 Mivel a Bernoulli-féle Szentpétervár-játék várható értéke végtelen, így a vele kapcsolatos veszteség várható értéke is végtelen. A józan ész számára elfogadhatatlan, hogy végtelen sokat kelljen fizetni a játékban való részvétel jogáért. Még egy véges nagy összeget is óvatosan kockáztatna bárki is, nemhogy végtelen nagy összeget tenne fel azért a lehetőségért, hogy nagyon kis valószínűséggel nagy nyereményt érhessen el. A Szentpétervár-paradoxon tehát azon az ellentmondáson alapul, hogy a játékban a nyeremény várható értéke végtelen nagy, az egyének mégsem lennének hajlandók sokat fizetni a részvétel jogáért. 
Ez is oka lehetett annak, hogy Bernoulli felfedezése hosszú időre feledésbe merült, s csak a huszadik század közepén került az érdeklődés középpontjába. ${ }^{15}$

Bernoulli (1738) munkájától kezdve folyamatosan az egyéni választást a gazdasági szereplők teljes izolálásának feltételezése mellett vizsgálták. Az egyének választása analizálható adott társadalmi csoport tagjaival együttes kontextusban, ám a szigorú ökonómiai alapvetés hiányzott minden szisztematikus megközelítésből, amely nagyszámú szubjektum közötti kölcsönkapcsolatokat vizsgálhatta volna.

Neumann-Morgenstern (1944) azt állította, hogy a bizonytalanság forrása mások törekvéseinek tudásán vagy nem tudásán alapul. Így cselekedve a döntési stratégiák úgy valósíthatók meg, hogy átváltási kapcsolat jön létre arról, mások törekvései miként viszonyulnak a mi szándékainkhoz.

A bizonytalanság, a játékelméleti stratégiák és a racionális döntés elmélete befolyásolja a gazdasági rendszerben hozott döntéseket, s e teóriák nincsenek tekintettel az olyan rendszer előzetes feltételezéseire, amelynek a döntéshozóit tökéletes elörelátásúnak tételezték. Az említett három teoretikus megfontolás azt tartalmazza, hogy a kockázat jelen van a gazdasági rendszerben, ami további hangsúly ama felismerés kapcsán, hogy fontos ezek figyelembe vétele a döntések meghozatala elött (Bernstein, 1998).

A várható hasznosság maximalizálásának beemelése a közgazdaságtani kánonba Neumann-Morgenstern (1944) müve által történt, amelyben a szerzők axiómák sorozatát fogalmazták meg az egyéni preferenciákra vonatkozóan, s bizonyítást adtak arra, hogy ha az egyén engedelmeskedik eme axiómáknak, akkor követi a várható hasznosság teóriát. Következésképpen a preferenciastruktúrát az axiómák sorozata rajzolja meg. Normatív interpretációban ezek az axiómák a racionális választás tanaként tekinthetők, s azok normatív vonzerejük alapján ítélhetők meg. Tény, hogy ha az egyén nem maximalizálja saját várható hasznosságát, akkor választásával megsérti a precíz axiomatikus princípiumok némelyikét, amelyek betartása viszont feltétlenül szükséges volna.

A várható hasznosság teória nagyon leegyszerüsítette a döntéshozatali folyamat matematikai formalizációját, mégis figyelmen kívül hagyta a döntési folyamat néhány fontos változóját, mint például a kockázatos helyzetek komplexitását s a döntéshozók kognitív erőforrásainak korlátait (Schilirò, 2017).

15 Tanulságos lehet felidézni KeynEs (1921:318-319) Szentpétervár-játékkal kapcsolatos ellenvetését, ami erősíti BER NOULLi hasznosság-paradigmájának jelentőségét: „... amennyiben jó szerencsénk lenne a dobásoknál, részben azért, mert nem tudjuk, mit tehetnénk ilyen sok pénzzel, ha megnyernénk; részben pedig nem hisszük, hogy valaha megnyerhetnénk, részben pedig mivel nem hisszük, hogy józan cselekedet lenne végtelen vagy akárcsak egy igen nagy összeget kockáztatni egy végtelen nagy összegért, amelynek megszerzése végtelenül valószínütlen”. 
A hasznosság konceptuális fogalomként tekinthető, amit azért vezetnek be, hogy tükrözze a kockázat számításba vételét a döntésben, a jövőbeni események értékelésekor ahelyett, hogy a döntéshozó saját lépéseit kizárólag a várható érték valószínűsége alapján tenné meg.

A várható hasznosság elmélete nem ad hiteles magyarázatot a kockázati tartózkodásnak a - mérsékelt tétek melletti - számbavételére, ami több szerző figyelmét is megragadta különböző specifikus kontextusokban, a hasznossági függvények különböző formái mellett. Ismert Arrow (1971) formalizáltkorlát-eredménye, amely szerint a várható hasznosságot maximalizálók (csaknem mindenütt) közel vannak a kockázatközömbösséghez, amikor a tétek tetszőlegesen kicsik. Rabin (2000) teóriát fogalmazott meg, amelyben kimutatta, hogy a várható hasznosság közömbösségi implikációja nem korlátozódik különös kontextusokra, különös függvényformákra vagy elhanyagolhatóan kicsi tétekre.

A várható hasznosság teóriája mint a racionális választás normatív modellje kezdettől fogva kétségeket vetett fel azzal kapcsolatban, hogy tud-e magyarázatot adni az aktuális választásokra (döntésekre). Például Allais (1953) megkérdőjelezte azt, hogy az egyének aktuálisan lineáris valószínűségi súlyok mellett választanak. Kahneman-Tversky (1981) viszont kimutatta, hogy az egyének választása a probléma keretezésének függvényében változik, s nem annak objektív vonásai alapján. Egyértelmünek látszik, hogy a veszteségtől tartózkodás, s mindegyik kockázatos választás izolálásának tendenciája egyaránt kulcskomponense kell, hogy legyen a kockázati attitüdök jó leíró teóriájának.

Starmer (2000) ugyanakkor jelzi, hogy a várható hasznossági elv megsértései jelentősen kevésbé gyakoriak, amikor az összes választás bizonytalan. Ez a megfigyelés különösen akkor érdekes, amikor a kockázatvállalási döntéseket időbeliségükben tekintik. Specifikusan a bizonyosságot és bizonytalanságot intertemporális döntésekben kombinálják: a jelen ismert és bizonyos, míg a jövő inherens módon kockázatos. Ez a megfigyelés akkor problematikus, ha valaki az időpreferenciát a kockázattól izoláltan szándékozik tanulmányozni (AndreoniSprenger, 2012). A huszadik század közepén Hicks (1931) még a kockázat várható hasznosság általi kanonizálását megelözően állította, hogy az egyének a kockázatos alternatívákat inkább a bizonytalan kifizetések várható értéke, varianciája és az eloszlás más lehetséges elemeinek alapján értékelték, mint a várható hasznosság alapján.

A bizonytalan helyzetekben való döntéshozatal lényegében kilátások/kimenetek közötti választás. A várható hasznosságon alapuló elméletek a döntéshozók kockázati attitűdjének megismerését szolgálják. Az emberi döntések magyarázatánál a várható hasznosság annyiban jelent mást a várható hozamhoz képest, hogy a racionális döntéshozó az egyes kimeneteket nem pénzbeni értékük szerint, hanem szubjektíven érzékelhető hasznosságuk alapján súlyozva minősíti. Neumann- 
Morgenstern várhatóhasznosság-koncepciója a bizonytalanság beépítését jelentette a hasznosságelméletbe. Ők tehát normatívan határozták meg azokat a kritériumokat, amelyek betartása esetén megvalósul a döntéshozó racionális viselkedése. ${ }^{16}$ A neoklasszikus elméletben preferenciákkal fejezik ki a hasznosságot. A racionális döntéshozó célja a hasznosság maximalizálása. Ebben a modellben az egyén teljes körűen informált, tehát biztos körülmények között választhat. A Neumann-Morgenstern-modellben az egyénnek a bizonytalanság körülményei között kell döntenie. Ebben a rendszerben a hasznosság mértéke az egyes bekövetkezési állapotokban elérhető hasznosságok várható értéke. Itt az egyéni preferenciák jelentik a választás alapvető eszközeit, így a hasznosság szolgál a preferenciák kifejezésére. Az egyén bizonytalanság melletti döntése nemcsak attól függ, hogy mit „nyerhet”, hanem attól is, hogy milyen valószínűséggel. A döntéshozó preferenciái tehát nemcsak a kimenetekre, hanem azok valószínüségére is vonatkoznak, és csak a végső kimenetekhez tartozó téteket és eredményeket figyelik. Azt nem lehet tudni, hogy az egyes döntési helyzetekben melyik környezeti állapot valósul meg, de az egyén ismeri valamennyi környezeti állapot bekövetkezésének valószínüségét. ${ }^{17}$

Az utóbbi korlátok említése magyarázza a leíró döntéselmélet megalapozásának szükségességét. Az egyén viselkedésének kiderítésére irányuló - s folyamatosan bővülő - empirikus vizsgálatok egyre több olyan döntéshozói jellemzőt azonosítottak, amelyeket a normatív elmélettel nem lehetett megmagyarázni. Gneezy et al. (2006) szerint a várható hasznosság teóriája, a kilátáselmélet s a kockázatos választás többi modellje azon a fundamentális feltevésen alapul, hogy a kockáza-

$16 \mathrm{Az}$ absztrakt modellek a leírás mellett magyarázatot is adnak az adott állapot kialakulásának feltételeire is. Ezért a modell érvényességének elsőrendű kritériuma a belső logikai konzisztencia, „az elméleti tisztaság”, amelyet az axiomatikus felépítés biztosít. Mivel a megfogalmazás hipotetikus módszerrel történik, az „ex ante” modellekben szereplő változók és paraméterek a priori és nem tapasztalati kategóriák. Emiatt a valósághűség, illetve az empirikus kezelhetőség nem szükséges feltétele a modell érvényességének.

$\mathrm{Az}$ axiomatikus módszer elterjedésével az empirikus-intuitív megközelítés átmenetileg háttérbe szorult a hipotetikus-logikai tudásteremtéssel szemben. Ennek veszélyére maga NEUMANN (1937:1965) figyelmeztetett, mondván: ha egy matematikai diszciplína messzire távolodik a tapasztalati forrástól, akkor degenerálódás fenyegeti.

17 Amennyiben a döntéshozó preferenciái kielégítik az axiómákat (teljesség, tranzitivitás, folytonosság, függetlenség), akkor létezik a preferenciákat reprezentáló lineáris hasznossági függvény, amely a kimenetek hasznosságának és a hozzájuk tartozó valószínűségek szorzatainak összege. Ez a függetlenségi axiómából következik: a hasznossági függvény a különböző, előre nem látható kimenetekre nézve speciálisan additív szerkezetű. Úgy is mondhatjuk, hogy egy szerencsejáték hasznát a kimenetek hasznának a valószínűségekkel súlyozott átlaga mutatja. A szerencsejáték hasznossága várható hasznosság, mégpedig a kimenetek hasznosságának várható értéke. A racionális döntéshozó az ilyen jellegű hasznosság-függvénye szerinti maximális várható hasznosságra törekszik. 
tos kilátások közüli egyéni választás kiegyensúlyozza a lehetséges konzekvenciák értékét. Ezért ezek a modellek azt igénylik, hogy a kockázatos kilátások értéke a kilátás legmagasabb és legalacsonyabb értéke közé essen.

Fontana-Marchionatti (2007) azt hangsúlyozza, hogy a valóságban a közgazdaságtan olyan változó és instabil tényezőkkel foglalkozik, mint „motívumok, várakozások és pszichológiai bizonytalanságok” a korlátozott tudás és a strukturális bizonytalanságok kontextusában: ez az elemzés tárgyát nagyon bonyolulttá teszi. Az időbeni homogenitásnak ez a hiánya kényszeríti a közgazdaságtant induktív elemzés végzésére; a valóságban - Keynes véleményének megfelelően - a teljes és pontos általánosítás nem lehetséges a gazdasági anyag természetének tulajdoníthatóan.

Minden fenntartás és kritika ellenére ma is úgy tekinthetünk a NeumannMorgenstern-modellre, mint a kockázat és bizonytalanság melletti választás fontos alapelvére. A várhatóhasznosság-elmélet értelmében minden bizonytalan kimenetű lehetőségnek (vagyoni helyzetnek) megtalálható a biztonságos kimenetü megfelelöje (hasznossági egyenértékese), amely a bizonytalannal közömbösségi viszonyban áll. Ez az alapja a Neumann-Morgenstern hasznossági függvénynek, amely az egyes vagyoni állapotokhoz tartozó hasznosságot úgy definiálja, mint az ezzel egyenértékű (közömbösségi viszonyban álló), bizonytalan kimenetű esemény várható hasznosságát.

A kockázat közgazdaságtani kánonba emelésének másik fontos mozzanata Markowitz portfóliódiverzifikációs teóriája volt. Akik Markowitz téziséből kiindulva gondolták tovább a kockázatos választás koncepcióját, azok anélkül voltak képesek továbbhaladni, hogy foglalkozniuk kellett volna a kockázatjellemzés nehéz feladatával; egyszerüen adaptálhattak egy készre formált explicit matematikai formulát. Érdekes, hogy Markowitz (1952) mérföldkőnek számító cikkében nem adott definíciót a kockázatra, hanem a következő egyszerű szabályt javasolta:

„a befektetőnek figyelembe kell vennie: a megtérülés kívánatos dolog, a megtérülés varianciája viszont nemkívánatos valami” (Markowitz, 1952:77).

Markowitz mindössze ennyit írt, s azt sem említette, hogy a megtérülés varianciája a kockázat közelítő mértéke lenne. Csupán annyit jegyzett meg, hogy a kockázat nemkívánatos dolog. Cikke végén még a következőket írta:

„... ha hozam és kockázat fogalma gyakran megjelenik a pénzügyi témájú írásokban. Rendszerint, ha a hozam kifejezést várható hozamra cserélik, a koc- 
kázatot pedig a megtérülés varianciájával helyettesítik, akkor a jelentés bizonyos fokú változásával kell számolni”. ${ }^{18}$

Markowitz azt is állította, hogy ha

„a kockázat kifejezést a megtérülés varianciájának fogalmával helyettesítik, akkor a jelentésben nagyon kicsi változás fog történni” (Markowitz, 1952:89).

Markowitz (1952) cikke hangsúlyozza a racionalitást a döntéshozatalban a kockázat mérésével és azzal, hogy hatékony portfóliót javasol, mint olyan megoldást, amely minimalizálja a kockázatot mint nemkívánatos elemet. Az ő modellje alapján a befektetők lehetőséget kapnak, hogy kiválaszthassák a számukra legmegfelelőbb kombinációt, adott pillanatban, a megtérülés alapulvételével. A befektetőket kockázatkerülőnek ábrázolja. Mindazonáltal az ellentétes teória, amit Kahneman-Tversky (1979) fogalmazott meg, azt feltételezte, hogy a befektetők veszteségkerülők és nem kockázatkerülők, ahogyan azt Markowitz fogalmazta. Ha ugyanazt a problémát másként csomagolják, akkor azt fogják választani, amelyik nyerést biztosít.

Egyértelmű, hogy a befektetők úgy tekintenek a kockázatra, hogy az potenciálisan egyaránt lehet masszív megtérülés és nagy veszteség forrása is, ami egyeseket kockázatkerülővé tesz, míg másokat kockázatkeresővé. Markowitz szerint a variancia koncepciója határozottan nemkívánatos elem, amit a befektető igyekszik minimalizálni. A variancia arra utal, hogy valamely eszköz megtérülési értékei milyen széles sávban ingadoznak az átlagos érték körül (Bernstein, 1998).

Markowitz a diverzifikációt ${ }^{19}$ azzal a céllal vezette be, hogy az segítsen csökkenteni a volatilitást. Ez azután történt, hogy megfigyelte: a befektetők többsége kockázatkerülö, mivel arra törekszenek, hogy alacsony megtérülésü vállalkozásokba

18 E jelentés azt sugallja, hogy a megtérülés varianciája lehet a kockázat közelítő mértéke, bár MARKowitz gondosan távol tartja magát ettől az asszociációtól.

19 Érdekességként érdemes megjegyezni, hogy jóval Markowitz diverzifikációs tézise előtt Keynes a gazdagság olyan allokációját preferálta, ahol a befektető tárcájában csupán a legkedveltebb értékpapírok szerepeltek. „(...) a befektetés helyes módszere, ha megfelelően nagy összeget fektetnek be olyan vállalatba, amelyikről azt hiszik, hogy tudnak róla valamit (...). Hibás az az elgondolás, hogy csökkenthető a kockázat azáltal, hogy túl sok vállalat között szórják szét a forrásokat, amely vállalatokról keveset tudnak, vagy nincs ok különösebb bizalomra irántuk (...), tudása és tapasztalata határozottan korlátozott, s ritkán terjed túl két vagy három vállalaton, adott időben, amelyekkel kapcsolatban személyesen teljes bizalommal vagyunk" (Keynes levele F. C. Scotthoz 1934 aug. 15-én; KeYNES, 1983).

Annak ellenére, hogy Markowitz portfólióteóriája szerint a befektetőnek kockázatos eszközök csupán egyetlen alapjába célszerü invesztálnia; abba, amely egyensúlyban maga a piaci portfolió. Fontos bizonyíték szól amellett, hogy a piaci portfolióba történő befektetés helyett a befektetők jelentős összeget tartsanak csupán néhány eszközben, olyanokat, amelyeket jól ismernek (vö. Warren Buffet befektetési módszerével a Berkshire Hathaway befektetési vállalkozásban, Boy Le et al., 2010). 
fektessenek be még akkor is, ha volna lehetőség beruházni kockázatosabb projektekbe magasabb hozam reményében (Chapman, 2019).

Markowitz fellépéséig a kockázat definíciója csak részben felelt meg az értelmezhetőség/kezelhetőség kritériumainak, két további lépésre volt szükség. Az első a variabilitás definiálása a megtérülés szórásaként, ahogy azt Markowitz tette. A másik, ami e megközelítést egyszerűvé, ugyanakkor nagy hatásúvá tette, hogy a befektető választását két dimenzióra redukálja. A „jó” dimenzió a befektetés várható megtérüléseként ragadható meg, a „rossz” dimenzió pedig e megtérülés varianciájaként vagy volatilitásaként tekinthető. Két útja van annak, ahogyan a várhatóérték-variancia fókusz igazolható: az egyik szerint a megtérülési értékek normális eloszlásúak, a másik annak a feltételezése, hogy a befektetőket hasznossági függvényük arra szorítja, hogy éppen a várható megtérülésre és a varianciára fókuszáljanak. Ami a normális eloszlás feltételezését illeti, az nem csupán szisztematikus, hanem éppen a várható értékkel és varianciával jellemezhető. Amennyiben a megtérülési értékek normális eloszlásúak, ebből következően a befektetők számára két változóra vonatkoztatva alapot szolgáltatnának a várhatóérték-variancia kerethez. Ezzel a feltételezéssel az a probléma, hogy a megtérülési értékek - a befektetések többsége esetében - nem lehetnek normális eloszlásúak. A legrosszabb lehetséges kimenet - részvénybe irányuló befektetés esetén - a teljes befektetett forrás elvesztése, ami -100\%-os megtérülésnek felel meg (és nem

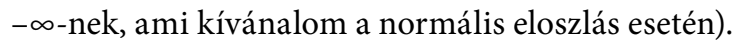

Bernstein (1998) joggal állapítja meg, hogy manapság a klasszikus tőkegondolatok gyaníthatóan olyan dolgoktól szenvednek, mint a ferdeség, a csúcsosság s más aszimmetrikus lefutásoktól. Kritikával illetik a nem lineáris hipotéziseket, s jobban nyomasztanak a diszkontinuitás miatti félelmek, mint az árazási volatilitások tényezői, s gyakran irrelevánssá válnak az egzotikus, új pénzügyi instrumentumok révén, amelyek ismeretlen alakban érkeznek, és ismeretlen kockázatot fedeznek le. Amint az eme kockázatokat definiáló számítások mind bonyolultabbá válnak, úgy a dimenziók, a kontúrok s a kockázat határai - ennek megfelelően - egyre homályosabbá válnak.

A kockázat vállalásában, érzékelésében, az annak való kitettségben fontos szerepe van az alsó oldali és felső oldali kockázat értelmezésének. Intuitív alapon az alsó oldali kockázat az, amelynek a döntéshozó számára fontosnak kell lennie a felső oldali kockázat helyett. Más szavakkal, ritkák az olyan befektetések, amelyeknek az eredménye a vártnál jobban alakul, megtérülése felfelé megy, idegességet és aggodalmat előidézve; ehelyett inkább az a jellemző, hogy a befektetések eredménye jelentősen lefelé tér el a várakozásoktól. A várható érték-variancia keretben, azonosan súlyozva a felső oldali volatilitást és az alsó oldali mozgásokat, nem tesznek különbséget a kettő között. 
Az intuíciótól eltéröen, a racionális mérlegelésben, normális vagy bármely más szimmetrikus eloszlás esetén a felső oldali és alsó oldali kockázat közötti megkülönböztetés irreleváns, mivel a kockázatok egyenértéküek. Viszont az aszimmetrikus eloszlás esetén lehet különbség a felső oldali és alsó oldali kockázat között. Az egyének kockázati tartózkodásának tanulmányozása arra mutat, hogy a veszteség miatti fájdalmat nagyobb súllyal illetik mint az ekvivalens nyerés okozta örömet. Az egyének a nagyon nagy pozitív kifizetéseket sokkal többre értékelik, mint amekkora valószínüséget kapcsolnak eme kifizetésekhez. Mint az imént említettük, a gyakorlatban a részvények és egyéb eszközök többségének megtérülése nem szimmetrikus. Ehelyett az eszközök megtérülési értékei széles farokrészt mutatnak, s nagyobb valószínűséggel jeleznek extrém pozitív, mint szélsőségesen negatív értékeket (mint már volt róla szó: ennek az a magyarázata, hogy a megtérülési értékeket korlátozza az, hogy nem lehetnek kisebbek -100\%-nál).

A fentiek fényében tekinthetjük relevánsnak Rudd-Clasing (1982) véleményét a kockázat értelmezéséről:

„A kockázat a beruházási kimenetek bizonytalansága. Technikailag a kockázat fogalma használatos a várható kimenet bizonytalanságának definiálásához, ami magában foglalja a felső oldali és alsó oldali lehetőségeket. Így, szemben a laikussal, aki az alsó oldali kimenetről kockázatként, a felső oldali kimenetről pedig esélyként gondolkodik, elméletileg a kockázat összegzéséhez mindkét irányú variabilitás mértékét használják”.

\subsection{A kockázat és bizonytalanság különbségének relativizálása}

A huszadik század közepétől éles fordulat következett be a neoklasszikus eszmevilágban a kockázat és bizonytalanság közgazdaságtani kezelését illetően. Ez kezdetben a kockázat és bizonytalanság különbségének kétségbevonását jelentette, majd később kísérletek történtek a kockázat és bizonytalanság egybeolvasztására, valamint a kockázat egyoldalú preferálására, s a bizonytalanság közgazdaságtani negligálására.

Friedman (1976), követve Savage (1954) korai interpretációját, tömören fogalmazta meg a kockázat és bizonytalanság megkülönböztethetetlenségének tézisét, konzisztens közgazdasági választásról írva.

„Frank Knight korszakalkotó munkájában éles megkülönböztetést tett a kockázat és bizonytalanság között: az elsőnél utalva olyan eseményekre, amelyek alá vannak vetve ismert vagy megismerhető valószínűségi eloszlásnak; az utóbbinál utalva olyan eseményekre, amelyekre vonatkozóan nem lehet numerikus valószínűségeket specifikálni. Én nem utaltam erre a megkülönböztetésre, mert nem hiszek az érvényességében. Követem Savage nézetét a 
személyes valószínűségről, amely tagad minden valós megkülönböztetést a két kategória között. Úgy kezelhetjük az egyéneket, mint akik numerikus valószínűségeket kapcsolnak minden elképzelhető eseményhez" (Friedman, 1976:282).

Sajátos módon Friedman (1976) Knight definíciói között keres argumentumokat a kockázat és bizonytalanság elválaszthatatlanságának igazolására. Knight mindig feltételezte, hogy az egyéneknek szubjektív hitük van a bizonytalanság viszonylatában, s ezek a várakozások ugyanolyan formájúak, mint a kockázat összefüggésében. Ennek kapcsán Knight ellentmondásról ír a következők szerint:

„a zavar abból a tényből adódik, hogy mi becsüljük véleményünk és anticipációnk validitásának és függőségének értékét, $s$ az ilyen becslésnek ugyanolyan formája lesz, mint egy valószínűségi ítéletnek, ami egy arány, megfelelö törttel kifejezve" (Knight, 1921:23).

Knight soraiból egyértelmű, hogy számára az egyén szubjektív várakozásai a fontosak. Friedman értelmezése azért nehezen érthető, mert Knight művének több pontján a jövőbeni események típusairól, azok esetleges biztosíthatóságáról, valamint a vállalkozók várakozásformáló szerepéről értekezett, kifejezve, hogy az esetek (különösen a gazdasági események) túlnyomó többségében nem lehet a matematikai valószínüségre vagy a történeti statisztikai bizonyítékra alapozni.

Brooke (2010) kiemeli: Knight a sikeres vállalkozó fö jellemzőjének azt tartotta, hogy megfelelő a jövőt előrejelző képessége. Idézi Knight ide vonatkozó megjegyzését:

„Az emberek különböznek abban, hogy milyen a percepciós és következteto képességük pontos ítéletek alkotására a környezeti események jövőbeni alakulásával kapcsolatban. Ez a képesség továbbá messze nem homogén; az egyik egy bizonyos szituáció előrejelzésében tűnik ki, más egyének esetében más problémák kapcsán, s a lehetőségek sora csaknem végtelen” (Knight, 1921: 241). Brooke azt is hozzáteszi - Knight álláspontjának erősítésére -, hogy a vállalkozó a döntés meghozatalakor nem csupán inherens képességére támaszkodik, de a képességgel kapcsolatos szerencséjének is szerepe van. A vállalkozó másik fontos jellemző tulajdonsága bizonytalanságot viselő képessége.

„....az ítéletalkotás bármely effektív foka, vagy a döntéshozatalé - szabad társadalomban - összekapcsolódik a bizonytalanságviselés fokával vagy a cselekedetekért viselt felelősséggel” (i. m. 15. o.).

Langlois-Cosgel (1993) fontos argumentumot fogalmazott meg a kockázat és bizonytalanság knighti megkülönböztetése kapcsán:

„...az üzleti műveleteket különböző - előre nem látható - események befolyásolják, amelyek benne rejlően előre jelezhetetlenek, vagy amelyek előrejel- 
zésére nem tennének kísérletet, s amelyek adaptálására sem tennék kísérletet (Langlois-Cosgel, 1993:129).

Régóta folyik a vita arról, hogy a bizonytalanságnak a kockázattal azonosítása a neoklasszikus közgazdaságtanban valójában milyen erők által mozgatott fejlemény volt. Általános vélekedés szerint ebben alapvető szerepe volt a közgazdaságtan matematizálásának, ehhez kapcsolódóan azonban a közgazdasági elmélet mind a diszciplínát, mind a metodológiát illetően kritikus jelentőségű újradefiniáláson ment keresztül. A Neumann-Morgenstern-megközelítéshez a teoretikus alapot Robbins (1933) argumentuma szolgáltatta abban a tekintetben, hogy a közgazdaságtan nem a javak vételét és eladását, a munkanélküliséget és az üzleti ciklust jelentette, hanem ehelyett az emberi magatartás specifikus aspektusát érintette: a szűkös erőforrások alternatív alkalmazási lehetőségei közüli választást. Boy (2009) felhívja a figyelmet, hogy Neumann-Morgenstern (1944) elsőként reprezentált a bizonytalanság közepette végbemenő választásra vonatkozó konzisztens teóriát, erősen ellenezve azt a felfogást, hogy a közgazdaságtan humán és pszichológiai elemei akadályoznák az emberi viselkedés formalizált kezelését a bizonytalanság körülményei között.

Hodgson (2011) arra a megállapításra jutott, hogy a neoklasszikus közgazdaságtan képviselőinek nagy része elvetette a bizonytalanság koncepcióját. Kapcsolat figyelhető meg a bizonytalansági fogalomnak a század közepe utáni hanyatlása és a közgazdaságtan erős formalizációja között a neoklasszikus közgazdaságtanban, főként azért, mert a bizonytalanságot nehéz beilleszteni a formalizált modellekbe. Ezért ezt a fogalmat egyszerűen száműzték a neoklasszikus teóriából. Lucas azt írta, hogy „a bizonytalanság eseteiben a közgazdasági megokolásnak nincs értéke" (Lucas, 1977:15). Ez emlékeztet Arrow (1951) elemzésére Knight bizonytalansági koncepciójával kapcsolatban, s arra a következtetésre, hogy „mérhető valószínűség” nélkül nem formálható elmélet a bizonytalanság esetére. Mind Arrow, mind Lucas fenntartja, hogy a „közgazdasági megokolás” és az elmélet csak kvantitatív lehet. A jelentős fordulat alapját az adta, hogy a neoklasszikus közgazdaságtan meghatározó gondolkodói a fenti kontextusban figyelmen kívül hagyták Knight és Keynes ama ellenvetését, hogy a bizonytalanság nem számszerüsíthető. Ehelyett vagy elvetették a nem kvantifikálhatóság koncepcióját, vagy a bizonytalanságnak szubjektív és kvantifikálható interpretációját adták.

A fordulat fontos indítéka volt Friedman (1953) nagy hatású véleménye, amely a közgazdászok legföbb céljává az elörejelzést emelte. Ö azt állította, hogy a közgazdasági elméletre úgy kell tekinteni, mint az elemzés „motorjára”, amely nem egyszerüen fényképen reprodukálja a világot, hanem elkötelezett az empirikus tények rögzítésének lehetetlen feladata iránt (1953:35). Ebből következően:

„Valóban fontos és jelentős hipotézisek találhatók ,feltevések’ eléréséhez, amelyek zabolátlanul pontatlan reprezentációját adják a valóságnak (...) s a hipo- 
tézis akkor fontos, ha sokat magyaráz meg kevésből (...) s ha absztrahálja az általános és kritikus jelentőségű elemeket a körülmények bonyolult és részletes tömegéböl, (...) továbbá hiteles predikciókat enged meg azok egyedüli bázisán. Ezért ahhoz, hogy a hipotézis pontos legyen leíró formájában, hibás kell hogy legyen saját feltevésében. (...) A tényszerü bizonyíték soha nem képes ,bizonyítani' a hipotézist, s csupán annak cáfolatára alkalmas" (Friedman, 1953:14).

Friedman (1976:282) egy későbbi művében jól érzékelhető az elmozdulás a tudás felöl a tudás rendelkezésre állása felé; ő a kockázatot úgy jellemzi, hogy az nem csupán az ismert, hanem a megismerhető valószínűségi tudást is fedi. Akik számára fontos kritériumnak látszott a kockázatnak a bizonytalanságtól való megkülönböztetésében, hogy vajon az e valószínűségekkel kapcsolatos megismerési szituáció kielégítő minőségű-e, azaz, hogy e valószínűségekhez (kielégítően) magas megismerési hitelességgel jutunk-e el. A bizonytalanságról értekezve Gardiner (2006:94) és Rawls (1999:134) a kockázatnak a bizonytalanságtól való megkülönböztetése érdekében nem vizsgálja, hogy vajon vannak-e valószínűségeink, hanem ehelyett azt kérdezik, hogy magas hitelességű valószínűségek vannak-e alacsony hitelességü valószínüségek helyett. Roser (2017) szerint sokan hisznek a bizonytalansági kontextus kockázatiba fordításában.

Bármi is volt a szándék a kockázat és bizonytalanság különbségének relativizálásával, a kockázat preferálásával s a bizonytalanság negligálásával vagy a kockázat és bizonytalanság egybeolvasztására tett kísérlettel, a lényeg az volt, hogy miután a neoklasszikus közgazdaságtan szembefordult a bizonytalanság koncepciójával, ez az elörejelzési funkció primátusa miatt történt.

Le Roy-Singell arra jutott, hogy a kockázat és bizonytalanság megkülönböztetésnek a közgazdaságtani fóáramban nem volt több, mint ceremoniális szerepe:

„különösen azok a közgazdászok, akik a neoklasszikus tradíciót követik, csak azért hívják segítségül a megkülönböztetést, hogy kiiktathassák a bizonytalanságot” (Le Roy - Singell, 1987:395).

Az álláspontokat közelíteni igyekvő szándék olvasható ki Boyle et al. (2010) véleményéből. Az egyének kockázat és bizonytalanság melletti választásának modellezése bonyolultabbá válik akkor, ha többet tudunk arról, hogy az egyének aktuálisan hogyan hozzák döntéseiket a kockázat és bizonytalanság körülményei között. Egyszerüen közelítve: a kockázat a bizonytalanság részhalmazaként tekinthető, ami vagy kvantifikálható vagy mérhető, ugyanakkor a bizonytalanság arra utal, hogy nem ismerjük a potenciális kimeneteket vagy azok bekövetkezésének valószínűségét.

A kockázat és bizonytalanság különbségének relativizálására, a két kategória egybeolvasztására, a bizonytalanság negligálására irányuló elméleti kísérletek- 
kel szemben állva, újólag felidézzük Knight vonatkozó gondolatait. Brockhaus (1980) szerint Knight specifikusan a bizonytalanságot „csökkenthető” és „nem csökkenthetö” komponensre osztotta. A csökkenthető bizonytalanság (véletlen) kockázatként definiálható; a nem csökkenthető (véletlen) bizonytalanság a „valós” bizonytalanság. A kockázat analizálható a matematikai valószínüség törvényei szerint; a valós bizonytalanság kívül esik a numerikus valószínűségi elmélet tartományán. A két kategória sem egymást kölcsönösen kizáró, sem független egymástól, s ugyancsak nem tekinthető egymástól szeparáltnak vagy elválasztható komponensnek.

A kockázat és bizonytalanság egybeolvasztásakor figyelmen kívül marad Knight (1921:13) maradandónak bizonyult tézise:

„A bizonytalanságot gyökeresen eltérő értelemben kell tekinteni a kockázat ismert fogalmától, amelytől sosem volt megfelelően elválasztva. A kockázat fogalmát rugalmasan értelmezik a mindennapi beszédben; a gazdasági diszkusszióban valójában két dolgot takar, legalábbis funkcionálisan, s azok a gazdasági szervezet jelenségével oksági kapcsolatban kategorikusan különbözők. (...) A lényeg az, hogy a kockázat bizonyos esetekben mérésre alkalmas menynyiséget jelent, míg máskor nincs ilyen megkülönböztető karaktere; továbbá messzire vezető és lényeges differenciák vannak a jelenség felmerülésében attól függően, hogy a mérhető bizonytalanság vagy a kockázat lesz használatra alkalmas, ami pedig különbözik a nem mérhetőtől, s ami valójában egyáltalán nem is bizonytalanság. Ennek megfelelően a bizonytalanság kifejezést a nem kvantitatív típusú esetekre korlátozzuk.”

Az utóbbi időben megfogalmazott álláspont a mai általános gondolkodást tükrözi:

„A jelenlegi közgazdasági megközelítés erősödően hanyagolja a kockázat és bizonytalanság közötti megkülönböztetést, s fókuszál a termelők és fogyasztók magatartásának modellezésére, s a piaci viselkedésre. Manapság a bizonytalanság a gazdasági élet vonása, a kockázat pedig kvantifikációt foglal magában a mérés szándékával úgy, hogy ezek az eszközök felhasználhatók hatásainak csökkentésére" (Motocu, 2009).

\subsection{A kockázatvállalás és kockázatviselés egységének megbomlása: a kockázatvállalás elszemélytelenedése}

Amikor a korábbiakban a kockázatvállalás és kockázatviselés eredetéről értekeztünk, akkor megállapítottuk, hogy ennek első aktora a tőkés piacgazdaságban a tulajdonos-vállalkozó, aki egyszerre volt a kockáztatott tőke tulajdonosa s a kockázat következményeinek viselője. A huszadik század középső harmadában 
kiteljesedett a tőketulajdon és tőkemüködtetés elválása, s ez új helyzetet teremtett a kockázat vállalásában és viselésében. Az így kialakuló tőkeműködtetői (menedzseri) túlhatalomról Jensen-Meckling (1976) értekezett nagy hatású cikkében. A szerzők előre látták annak kockázatát, hogy a tőkeműködtetők hozhatnak döntéseket a maguk javára, s az aktuális hitelnyújtók és részvénytulajdonosok (rövid távú) kárára. Denning (2014) azonban felhívja a figyelmet arra, hogy Jensen-Meckling nem látta előre a részvénytulajdonosok érdeksérelmének kockázatát, ennek a kombinációnak a veszélyét, hogy ugyanis a tőkemüködtetők konspirálhatnak a részvénytulajdonosokkal, akik érdekeltek lehetnek abban, hogy rövid távú nyereségként értéket vegyenek ki a vállalatból a vevők, a foglalkoztatottak, a szervezet, a közösség rovására, amelyben a vállalati szervezet müködik, s végső soron az egész társadalom kárára.

Egy további argumentum, hogy a tőkeműködtetők manipulálhatják a részvényárat a vállalat részvényeinek visszavásárlásával. A Jensen-Meckling-cikk megjelenésekor az ilyen gyakorlat nem volt tömeges. Denning (2014) szerint a szerzők nem tudták elképzelni, hogy ha feloldják a korlátokat, akkor a tőkemüködtetők elköteleződhetnek az ilyen gyakorlat mellett, dollár-ezermilliárdokat szerezve ily módon, ami valójában nagybani részvényár-manipuláció. Az elmélet képviselői azt a kockázatot sem látták előre, hogy a tőkemüködtetők képesek volnának időzíteni különböző cselekedeteik kombinációját rendelkezésük szerint, hogy személyes hasznuk nagyobb legyen a közönséges részvénytulajdonosokénál.

A problémák keletkezése nem áll meg a menedzserek (tőkeműködtetők) túlhatalmából származó anomáliáknál. Az intézményi részvénytulajdonosok elnézik azt, amit a vállalatok - ebben az összefüggésben - tesznek, sőt időnként még ösztönzik is azt, a regulátorok pedig gyakran közömbösek a szisztematikus hibákkal s a szabálytalanságokkal szemben; azon a címen nem lépnek fel, hogy az érintett vállalatok „túl nagyok, hogy bukjanak”. Az értékelési ügynökségek elfogadják a jogellenes cselekményekből származó profitokat. Az elemzők ugyancsak üdvözlik a rövid távú nyereségeket, s objektíve a vállalati érték hosszú távú erózióját.

A vállalati világ és a pénzügyi piacok ily gyökeres átalakulása utat nyitott a tőke mértéktelenül nagy fokú koncentrációja előtt. Denning (2014:10) idézi Friedman egyik híres aforizmáját:

„...a koncentrált hatalom nem válik ártalmatlanná azok jó törekvései által, akik azt megteremtették.”

Friedman természetesen a kormányzatra (államra) utalt, amelynek túlhatalmára érzékeny volt. Ugyanakkor e prófétikus kritika a privát szektoron belül kialakuló (bármilyen színezetü) túlhatalommal szemben nem fogalmazódott meg. Döntően a profithoz történö, erőltetett és pánikszerü menekülés, annak mindenek elé 
helyezése kevesek kezében összpontosuló, koncentrált hatalomhoz vezetett, amelyet Friedman oly határozottan el akart kerülni. A koncentráció eltorzította a verseny folyamatait annak a sajátos érdeknek az érvényesülésével, hogy egyre több jusson keveseknek a tőkevagyonból.

A huszadik század utolsó harmadától a közgazdaságtanon belül megformálódott a pénzügyi közgazdaságtan (financial economics) diszciplínája, amelynek meghatározó szerep jutott a befektetések, a vonatkozó pénzügyi piacok és a kockázat analízisében. A pénzügyi közgazdaságtan olyan világot feltételez, ahol a vállalkozók redundánsak, s a pénzügyi piacoknak felsőbbrendű tudása van a vevői szükségletekről, az erőforrások potenciáljáról. Ehret (2012) arra hívja fel a figyelmet, hogy a pénzügyi közgazdaságtani modellek szisztematikusan felváltják az értékvezérelt befektetéseket az elmélet irányitotta spekulációval. Az újonnan megformálódott diszciplína tétele, hogy az individuális befektető nem győzheti le a piacot: ha a piacok racionálisak, akkor az egyéni befektető a legjobb esetben azt remélheti, hogy eléri az egyensúlyi árat, amely a vevők és eladók kompetitív egymásra hatásából származik. Specifikusabban, a pénzügyi közgazdaságtan azt feltételezi, hogy a konvencionális, értékvezérelt befektetési megközelítés csaknem bizonyosan hibás. Az értékvezérelt megközelítésben a befektetők becslik a befektetésből származó jövőbeni jövedelemáram jelenértékét. Mivel a jövőbeni jövedelem bizonytalan, ezért a konvencionális befektető felhasználja saját tapasztalatait, az információs hálózatokat $s$ benső érzéseit a befektetés értékének becsléséhez. Ama feltevés mellett, ha egy befektetési tétel - például részvény, kötvény, tőzsdei áru - ára mozog az egyensúly felé, a konvencionális befektető csaknem bizonyosan téved, mivel a legjobb becslése is eltérhet az egyensúlyi ártól. Erre alapozva írja Taleb (2007), hogy a pénzügyi közgazdaságtan szerint a pénzügyi piacok által mozgatott spekulációs stratégiák túlszárnyalják az értékvezérelt befektetési stratégiákat.

A pénzügyi közgazdaságtani modellek azt feltételezik, hogy az eszközárak normális eloszlást követnek. Amennyiben készítőik bíznak a tiszta statisztikai megközelítésben, akkor a befektetők konstruálhatnak olyan befektetési portfóliókat, amelyek a legjobban illeszkednek individuális megtérülésmaximalizáló vagy kockázatredukáló attitűdjükhöz (Fox, 2009; Markowitz, 1991).

Ehret (2012) kiemeli, hogy a pénzügyi közgazdaságtan a befektetők számára a modellek elegáns rendszerét kínálja, amely lényegében a pénzügyi piacok adatainak kizárólagos alkalmazásával teszi elérhetővé egy eszköz jövőbeni árának becslését. A pénzügyi közgazdaságtan törekszik a konvencionális értékalapú befektetési müveletet a tudomány által vezérelt tevékenységgé transzformálni a gazdasági elmélet és a statisztikai kalkuláció segítségével.

A spekulánsok, akik szisztematikusan feltételezik az egyensúlyi árakat, elválasztják az árakat a produktív lehetőségektől és a kockázattól, ami érzéketlenné te- 
szi őket a ritka események konzekvenciáival szemben. A hipotetikus egyensúlyi árak az üzleti teljesítmények értékelését is eltorzítják. A pénzügyi közgazdaságtan helyettesíti a vállalkozók szerepét egy elegáns rendszerrel, amely a gazdasági elméletből, a sztochasztikus modellekből s az értékpapír-kereskedésből áll. Ehret (2012) azt hangsúlyozza, hogy a pénzügyi közgazdaságtan eltorzítja az üzleti lehetőségek feltárását, túl a pénzügyi piaciár-inkonzisztenciákon. A vonatkozó modellek nem képesek releváns információkat szolgáltatni a vállalkozók számára, akik mérni és irányítani akarják üzleti teljesítményüket.

A neoklasszikus eszmerendszer tradíciójában a pénzügyi közgazdaságtan feltételezi, hogy a piaci résztvevők elégséges tudás birtokában vannak, hogy racionális döntéseket hozhassanak. Hayek (1945) kihívást intézett e pozíció ellen, állítva, hogy az áraknak egyensúlyi helyzetben van jelentése, ahol a vevők jelezhetnek lefedetlen szükségleteket, a termelők pedig hatékony módon jelzést adhatnak kihasználatlan erőforrásaikról. Mindaddig, amíg az árak más módon vagy más okokból képződnek, azok abbéli potenciálja, hogy a gazdasági kommunikáció jelentéssel bíró eszközei legyenek, talajukat vesztheti.

A vállalkozók úgy irányítják üzletüket, mint produktív választ a bizonytalanságra s az egyének tudáshiányára. Míg a racionális piaci megközelítés teljes tudást $s$ a sztochasztikus módszerek alkalmazását feltételezi a bizonytalanság kezelésére, addig a vállalkozó igyekszik feltárni a bizonytalanságot, s úgy irányítani a projekteket, hogy kihasználják a lehetőségeket (Lackmann, 1977; Young, 1987). Ehretnek (2012) igaza van abban, hogy a pénzügyi közgazdaságtan alkalmazása elválasztja a vállalkozói ítéletet az eszközök értékelésétől, így gyengítve a vállalkozók elszámoltathatóságát.

A huszadik század végére kialakuló vállalattulajdonlási és társaságirányítási formáció lényegét jól ragadja meg Fama (1980) véleménye:

„...a vállalatirányítás olyan menedzserek kezében van, akik többé-kevésbé elkülönülnek a vállalat értékpapír-tulajdonosaitól. Mivel a befektető értékpapír-tulajdonos sokféle vállalat értékpapírjait birtokolhatja, pontosan annak elkerülése érdekében, hogy vagyoni helyzete túlzott mértékben függjön bármely vállalattól is, így semmiféle érdeke nem füzi ahhoz, hogy személyesen nyomon kövesse bármely vállalat tevékenységét. Röviden kifejezve, a kockázatviselés - részvényesi oldalról preferált - mellőzése azt idézi elő, hogy az értékpapír-tulajdonos nagymértékben elhatárolódik a vállalat ellenőrzésétől.”

Az utóbbi három évtizedben a kockázat és bizonytalanság gazdasági-pénzügyi döntésekben történő kezelésében újabb fejlemények jelentkeztek. A pénzügyi rendszer utóbbi évtizedekben kiteljesedett deregulációja és liberalizációja egy olyan - pénzügyi piaci szereplőkből álló - réteget kapcsolt be a piacba, amely felborította a tulajdonosok közötti törékeny egyensúlyt. Az új réteg szereplőit a 
pénzügyi közgazdaságtani irodalomban financialistáknak is nevezik. Idetartoznak a vállalatok felső pénzügyi vezetői, a pénzügyi elemzők és tanácsadók. Eme új rétegként bemutatott professzionális vagy technobürokratikus aktorok a szabad pénzalapokkal bíró egyéni és intézményi befektetők nevében kereskednek, ezért díjazásként kamatot, osztalékot vagy befektetési hozamjáradékot kapnak. A vállalaton belüli - addig korlátok nélküli - menedzseri túlhatalom és érdekérvényesítés körülményei gyökeresen megváltoztak.

A pénzügyi rendszer deregulációja és liberalizációja nyomán a korábbi kétszereplős „tulajdonos-tőkeműködtető menedzser” reláció háromszereplőssé vált az ún. financialistáknak a rendszerbe kerülésével. E „harmadik erő” a vállalati menedzserek fölébe kerekedett, a vállalati menedzserek a technobürokrácia érdekei szerint cselekedtek. Ez a müködési, finanszírozási, irányítási és kompenzációs kockázat akkumulálódásához vezetett, s a növekvő kockázat egyre nehezebben allokálhatóvá, azt is mondhatjuk, hogy lényegében gazdátlanná vált. Csaknem mindennapos gyakorlat lett a „mások” forrásainak kifejezetten nem prudens módon történő kockáztatása. A vállalatkormányzási rendszer nem tudta eltéríteni a menedzsereket a veszélyes és káros kockázatvállalástól, s ennek súlyos veszteség lett a következménye.

Dizikes (2010) joggal mutat rá arra, hogy Knight kockázat és bizonytalanság közötti megkülönböztetése segíthetne analizálni a pénzügyi vállalatok, a befektetési intézmények, a financialisták és a tőkepiac egészének magatartását. A befektetési intézmények, $s$ tágabb értelemben a pénzügyi piacok szereplői a pénzügyi válság (2008-2009) előtt és után is megelégedettséggel tekintenek saját precíz kockázatértékelésükre, s bizalommal gondolhatják magukról, hogy a knighti kockázat feltételei szerint működnek, ahol ők ítélhetik meg a jövőbeni kimenetek tétjeit. Amikor viszont ezek a szereplök felismerik, hogy értékelésük hamis, akkor megértik, hogy valójában a knighti bizonytalanság kondiciói mellett cselekszenek, s kereskedésük visszafogására kényszerülhetnek. Amikor a befektetők felismerik, hogy a kockázattal kapcsolatos feltevéseik tovább nem igazak, s a knighti bizonytalanság kondíciói érvényesülnek, akkor a piacok tanúi lesznek a „minőség felé irányuló romboló igyekezetnek”, amelynek keretében szabadulni igyekeznek kétes portfólióiktól, menekülve a biztosnak vélt befektetések felé (kincstári kötvény, nemesfém).

A kockázat hibás felmérése, a vállalati teljesítmények hamis színben feltüntetése, az árfolyam-növekedés hajhászása mind-mind értékelési egyensúlytalanságot okoz, s emiatt időröl idöre számolni kell a más gazdasági szereplők rovására vállalt kockázatok felhalmozódásával. Azóta, hogy elkezdődött a tulajdonlás és a tőkeműködtetés szétválása, a kockázatvállalás személytelenné, telepíthetetlenné és korlátozhatatlanná vált. A menedzserek saját hasznossági optimumát követő expanziós beruházások és akvizíciók, az elemzők és tanácsadók profitvárakozási 
követeléseinek teljesítése és sok hasonló mozzanat tipikus példája a másik aktor kockázatára hozott döntésnek.

\section{TANULSÁGOK}

Emmett (2018) éleslátóan állapítja meg, hogy a nagy művek iránt nem azért marad meg az érdeklődés később is, mert üzenetük időtlen, hanem azért, mert olyan ideákat közvetítenek a gondolkodók és a gazdasági szereplők új generációi számára, amelyek értéket adnak hozzá azok intellektuális és vállalkozási céljaikhoz. Úgy véljük, hogy mind Knight (1921), mind Keynes (1921) müve ilyennek bizonyult.

Knight kockázat-bizonytalanság megközelítése és Keynes bizonytalanságkezelése a maga korában rendkívüli fontosságú, új felismerés volt, amely évtizedekre elveszhetett, s csak akkor fedezték fel újra, amikor a vonatkozó elmélet - releváns teória hiányában - keveset tudott megmagyarázni a váratlan eseményekből. Kivétel volt Shackle (1949; 1972), aki egész pályáján a közgazdaságtan, az idő, a várakozások és a bizonytalanság kritikus összefüggéseivel foglalkozott. Az évek során Shackle visszaintegrálta a várakozásokat és a bizonytalanságot a tradicionális keynesi rendszerbe, s a fókuszértékek logikája alapján kifejlesztett egy mechanizmust, amely konzisztens azzal a töredezett képpel, amelyet Keynes (1937) müve adott.

Shackle (1972) úgy látta, hogy a társadalom jövőjét nem láthatják úgy az emberek, mint valami előre meghatározott dolgot, olyasvalamit, amelynek felfedezése objektíven várható. Szerinte a jövőt nem lehet előre jelezni, ám az emberek elképzelhetik a jövőt, és szubjektív várakozásokat formálhatnak a jövőre vonatkozóan. $\mathrm{Az}$ emberek cselekszenek és interaktivitásban vannak eme elképzelések és várakozások bázisán. Arthur (2013) hangsúlyozza, hogy a jövő ezekből az (inter)aktivitásokból emelkedik ki, ez kreálhat meglepetéseket: pozitívakat és (néhány ember számára) negatívakat. Az emberek válaszolnak arra és adaptálódnak ahhoz, amit a jövő mutat, amikor jelenné válik, megint csak a várható jövő bizonytalanságának fényében. Arthur kiemeli, hogy ez egy megszakítatlan folyamat, egyaránt jellemezhető alulról felfelé irányuló és fentről lefelé haladó kauzalitással, ismerhető végpont és egyensúly nélkül. Az egyének akciói és interakciói együtt determinálják a jövőt, s a felemelkedő jövő az egyik determinánsa az egyének akcióinak és interakcióinak (Financial Risk, 2008).

A 2008-2009-es pénzügyi válság feltárta, hogy a pénzügyi intézmények képtelenek hatékonyan megítélni befektetéseik kockázatosságát. Emiatt a válság újra ráirányította a figyelmet korábbi évtizedek kockázatgondolatára: a knighti bizonytalanságra. Eszerint a bizonytalanság körülményei közötti választásról akkor beszélhetünk, amikor sem a döntési kimenetek, sem azok bekövetkezési 
valószínűségei nem ismertek. Szó lehet magának a döntéshozónak a bizonytalanságáról, ami azt jelenti, hogy nem ismeri, tehát nem is tudja átlátni a lehetőségeket, nem tudja elkerülni a számára kedvezőtlen kimeneteket, nem tud jó döntést hozni, és végeredményben nem képes javítani a helyzetén. Lehet, hogy a konkrét választások sikertelensége még tovább fokozza a döntéshozó bizonytalanságát. Ez teljesen szubjektív, és az egyén tudatállapotától függ. Az is előfordulhat, hogy két biztonságos esemény közül sem tudunk könnyen választani, bár a kimenetek és a valószínüségek egyaránt ismertek. Knight szerint bizonytalanság esetén nincs lehetőség objektív mérlegelésre.

Dizikes (2010), kissé átfogalmazva Knight kockázat-bizonytalanság felfogását, azt írja, hogy a kockázat olyan helyzetekre alkalmazható, ahol nem ismerjük az adott szituáció kimenetét, ugyanakkor pontosan mérhető a kockázatvállaló által tett tét. Másik oldalról, a bizonytalanság olyan helyzetekre alkalmazható, ahol nem ismerjük az ahhoz szükséges összes információt, hogy pontosan meghatározhatnánk a tétet. Knight azt írta, hogy fundamentális különbség van az ismert kockázat vállalásáért kapható jutalom és egy olyan kockázat feltételezése között, amelynek értéke nem ismert. Az ismert kockázat könnyen konvertálható effektív bizonyossággá, míg a valódi bizonytalanság - ahogy Knight nevezte - nem fogékony a mérésre.

Knight (1921:43) külön kitért a kockázat és biztosítás kapcsolatára, amikor a következőket írta:

„Megengedhető, hogy a vállalkozó bizonyos esetekben - fix költség fejében - megszabadulhat a kockázattól biztosítás révén. Ám a biztosítási aktussal a vállalkozó sok mindenről lemond üzletével kapcsolatban; annak kinyilvánításával, hogy a vállalkozó eliminálhatja az összes kockázatot a biztosítás segítségével, nem marad jövedelme olyan célok megoldására, mint a menedzserek kompenzációja és a monopolprofit. Abban a mértékben, amennyiben az üzletember biztosítást köt, korlátozza szokásos funkcióinak gyakorlását, s a kockázatot csupán áttestálja a biztosítóra, ami annak az elfogadásával maga is vállalkozóvá válik, s egy meghatározatlan maradék vagy profit várományosa lesz. A biztosító jutalma nem az általa kapott prémium lesz, hanem az a különbség, ami a prémium és az általa elszenvedett veszteség között van.”

Knight álláspontja szerint a gazdasági események annyira komplexek, hogy az előrejelzés mindig viaskodás a „valódi” bizonytalansággal, s nem a kockázattal; lehet, hogy a kockázat előrejelzéséhez használt múltbeli adatok egyáltalán nem tükrözik a folyó kondíciókat. Knight nézete szerint a legjobb, ha a „kockázatot” a fokozottan irányított környezetre alkalmazzák, mint például a szerencsejátékok tiszta esetváltozatai, s a „bizonytalanságot” csaknem minden más esetre alkalmazhatják. E megkülönböztetés természetesen a mérhetőségre vonatkozik. A döntéshozó a kockázat vállalását nem kerülheti el, legyen az önként vállalt 
vagy kényszerüen elviselt; lehet az rendszeres vagy váratlan veszély; elképzelhető explicit vagy látens kockázat; vagy pedig ellenőrizhető versus ellenőrizhetetlen kockázat. Bármely változat jöjjön is szóba, a gazdasági döntéseket övező bizonytalanság kiiktathatatlan.

Az utóbbi évtizedekben a bizonytalanságnak a neoklasszikus eszmevilágból történt kiiktatását követően egyre komplexebb pénzügyi termékek s egyre komplikáltabb kockázati instrumentumok jelentek meg a piacokon, s egyre kevesebb befektetést soroltak a bizonytalanság osztályába. S ahogy Emmett (2018) utal erre, történt két fontos esemény. Az egyik a 2008-2009-es globális pénzügyi válság, amelyet jórészt azok a pénzügyi kockázatot kezelni hivatott instrumentumok idéztek elő, amelyekről azt állították, hogy csökkentenék a kockázatot. A másik esemény Taleb (2007) publikációja volt, amely a „fekete hattyư ” analógiával felélesztette Knight bizonytalanságfogalmát, mivel a jelzett szimbólum a „fokozottan valószínütlen eseményt” jelölte. Taleb cáfolta, hogy a bizonytalanság kezelhető lenne a kockázati piacokkal. Ö ehelyett megfogalmazott néhány knighti argumentumot. Taleb szerint, mivel nem tudjuk teljesen megvédeni magunkat a bizonytalansággal szemben, ezért robusztusságot kell beépítenünk vállalatunkba, a közgazdasági elméletbe, a társadalom intézményeibe, ellenállni a bizonytalanságnak, s kerülni a káros kimeneteket. Emmett (2018) szerint ezek a cselekedetek költségeket igényelhetnek, korlátozhatják a vállalati müködés egyéb aspektusait, s nyitottságot biztosíthatnak az új lehetőségek irányában.

Keynes (1921) logikai valószínűségi tana köztes pozíciót foglalt el a valószínűség szubjektív és objektív elmélete között. A valószínűségről írott értekezése legvégén olyan versikét közöl, amely az ő különleges véleményét mutatja be. ${ }^{20}$ Keynes ebben a valószínűséget kétélü dologként érzékelteti, amelynek kettős jelentése van. Sakai (2015:4) úgy értelmezi, hogy az egyik oldalról lehet hamis és veszélyes fogalom, ami még az igazság ellenségévé is válhat. Másik oldalról ez elvezet az igazsághoz abban az értelemben, hogy a gyenge oldal szerepét játssza az igazságkeresés folyamatában. Ebben az értelemben a valószínűség fogalma egyaránt lehet sivár és gyümölcsöző. Valójában nincs olyan, aki előre tudná, hogy melyik változat alkalmazható.

Mind Knight (1921), mind Keynes (1921) olyan eseményekre vonatkoztatva alkalmazta a bizonytalanság kifejezést, amelyekre nem volt számítható valószínűség. Knight úgy tekintett a kockázatra, mint „mérésre hajlamos” mennyiségre, míg a bizonytalanságra mint „nem mérhetőre” és „nem kvantitatívra” (1921:19-20).

20 „Ó, hamis és veszélyes valószínűség, Ellensége az igazságnak, s barátja a bűnnek,

Mely homályos tekintettel láttatja a valót..." (KeYNes, 1921:466). 
Keynes szerint a bizonytalanság olyan helyzetekre vonatkozik, ahol „nincs tudományos alap, amelyre támaszkodva számítható valószínüség formálható volna” (Keynes, 1937:217).

Knight és Keynes a közgazdaságtan két nagy gondolkodója újdonságként vezette be a gazdasági elméletbe és elemzésbe a nem mérhető bizonytalanságot, s mélyrehatóan vizsgálta, hogy miként különbözik az a mérhető kockázattól. Fontos látni, hogy a két kifejezés szándékosan elválasztotta egymástól a kockázatot és a bizonytalanságot. Knight a következőket írta erről:

„A bizonytalanságot radikálisan meg kell különböztetni a kockázat jól ismert fogalmától, amitől soha nem volt megfelelően elválasztva. A ,kockázat' kategóriája, amelyet oly szabadon használnak a mindennapi beszédben és a közgazdasági diszkusszióban, valójában két dolgot takar, amelyek funkcionálisan kauzális kapcsolatban vannak a gazdasági szervezettel, ám kategorikusan különbözők" (Knight, 1921:19).

Sakai (2015) is hangsúlyozza, hogy Knight a bizonytalanságot radikálisan megkülönböztette a kockázattól, mivel a kockázatnak és bizonytalanságnak kategorikusan eltérőnek kell lennie. Ehelyütt maga Knight is erős kifejezéseket használ, mint „radikálisan eltérő” és „kategorikusan különböző”. Természetszerüleg felmerül a kérdés, hogy miért is különbözik egymástól ez a két dolog. Ebben az összefüggésben Knight a következőket jegyzi meg:

„A mérhető bizonytalanság vagy ,kockázat’ alkalmas szóhasználat, ami eddig különbözik a nem mérhetőtől, ami valójában nem is bizonytalanság. Ennek megfelelően ezt a kifejezést mint ,bizonytalanságot' olyan esetekre korlátozzuk, amelyek nem kvantitatív típusúak. Ez a ,valódi’ bizonytalanság, s nem kockázat, állítva, hogy ez formál alapot a profit igazi teóriájához, s számít az aktuális és teoretikus verseny elválásában (Knight, 1921:20). ${ }^{21}$

Bernstein (1996:215) úgy véli, hogy a bizonytalanság mint „radikálisan elkülönülő fogalom” nem lehetett alkalmas arra, hogy a választási döntés domináns mintázata legyen olyan időben (a huszadik század második felében), amikor a gondolkodók a közgazdaságtan tudományossá tételére törekedtek annak tanulmányozásával, hogy ez a tudomány hogyan viselkedik akkor, ha az egyének abszolút racionálisak, s önmagukat csupán gazdasági alapon irányítják.

21 Von Mises $(1928 ; 1957)$ még határozottabban fogalmazza meg a bizonytalanság jelentőségét Keynes rendszerében, amikor azt írja: Keynes mindenki számára demonstrálta, hogy a gazdasági cselekvés valós motorja a bizonytalanság volt. Bizonytalanság nélküli világban, amely előre pontosan meghatározott (és elörejelezhető), az egyén a logikai és szükséges cselekvések puszta végrehajtójának szerepére korlátozódik. 
Keynesnél az animal spirits esetében a hangsúly - amit az „emberi természet tulajdonságaira” helyezett - az az argumentum, amely igazolta, hogy „pozitív cselekedeteink nagy része inkább függ spontán optimizmustól, mint matematikai várakozásoktól” (Keynes, 1936:161). Skidelsky (2009:135) szerint a keynesi bizonytalanság a jövőhöz kötődő pozitív és negatív hitekhez kapcsolódik. Ezek közül egyik sem magyarázható megfelelően, mivel ki vannak téve váratlan változásoknak. Skidelsky úgy interpretálja Keynes gondolatát, hogy ha nincs módunk ismerni a jövőt, akkor az a racionális - s mindenekelőtt indokolt -, hogy a várakozásokkal összhangban cselekszünk, amelyek származhatnak konvenciókból, alapelvekből, tradíciókból és szokásokból.

\section{HIVATKOZÁSOK}

Akerlof, G. A. - Shiller, R. J. (2009): Animal Spirits: How Human Psychology Drives the Economy and Why it Matters for Global Capitalism. Princeton, N. J.: Princeton University Press.

Andreoni, J. - Sprenger, C. (2012): Risk Preferences are t Time Preferences. American Economic Review, 102(7), 3357-3376.

Arrow, K. (1971): Essay in the Theory of Risk Bearing. Markham Publishing Company.

Arrow, K. (1971): Insurance, Risk and Resource Allocation. University of Illinois at Urbana.

Arrow, K. (1951): Alternative Approaches to the Theory of Choice in Risk-Taking Situations. Econometrica, 19, 404-437.

Azariadis, C. (1981): Self-fulfilling Prophecies. Journal of Economic Theory, 25, 380-396.

Balgah, R. A. - Buchenrieder, G. (2012): Risk, Uncertainty and Decision Making. An Empirical Test of Irving Fisher's Theory of Interest. Bamenda: Catholic University of Cameroon, 1(2), 33-41.

Bernoulli, D. (1738; 1955): Exposition of a new theory on the measurement of risk. Reprinted in 1955 in Econometrica 22(1), 23-36.

Bernstein, P. L. (1995): Risk as a History of Ideas. Financial Analyst Journal, 51(1), 7-11.

Bernstein, P. L. (1996): Against the gods: the remarkable story of risk. New York: Wiley.

Bogle, P. - Garlappi, L. - Uppal, R. - Wang, T. (2010): Keynes Meets Markowitz: The Trade of Between Familiarity and Diversification. AFA Atlanta Meetings Paper, 41.

Boy, N. (2008): Calculating Risk and Uncertainty. King's College Risk Research Symposium, 10.

Brockhaus, R. H. (1980): Risk Taking Propensity of Entrepreneurs. Academy of Management Journal, 29(1), 509-520.

Brooke, G. T. F. (2010): Uncertainty, Profit and Entrepreneurial Action: Frank Knight's Contribution Reconsidered. Department of Economics, University of Auckland. New Zeland, 25.

Butos, W. N. - Koppl, R. G. (1995): The Varieties of Subjectivism: Keynes and Hayek on Expectations. History of Political Economy, 29(2), 1-61.

Carabelli, A. (1988): On Keynes's Method. London: Mac Millan

Chapman, K. (2019): The Concept of Risk in Economics. Free Essay Samples Database, 19.

Davidson, P. (1991): Is Probability Theory Relevant for Uncertainty. A Post Keynesian Perspective. Post Keynesian Economics, 5(1), 129-143.

Denning, S. (2014): The Unanticipated Risk of Maximizing Shareholder Value. Forbes, 14 Octobre. 
Dequech, D. (1999): Expectations and confidence under uncertainty. Journal of Post Keynesian Economics, 75(1), 643-669.

DEQUeCH, D. (2000): Fundamental uncertainty and ambiquity. Eastern Economic Journal, 26, 41-60.

Dequech, D. (2005): Confidence and Alternative Keynesian Methods of Asset Choice. Review of Political Economy, 17(4), 533-547.

Dizikes, P. (2010): Explained: Knightian uncertainty. MIT News, June 2

Dow, A. - Dow, S. C. (2011): Animal Spirits Revisited. Manuscript 1087, Berkley Electronic Press, 23.

EHret, M. (2012): Financial socialism - the role of financial economics in economic disorganization. Nottingham: Business School 34.

Емmetт, R. (2018): A Century of Risk, Uncertainty and Profit. Econlib Featured Article, Dec. 3.

Epper, T. - Fehr-Duda, H. (2018): The Missing Link: Unifying Risk Taking and Time Discounting. Working Paper 96, University of Zürich.

Epstein, L. G. - ZIN, S. E. (1989): Substitution, Risk Aversion and Asset Returns: A Theoretical Framework. Econometrica, 7(4), 937-969.

FAmA, E. F. (1980): Agency problems and the theory of the firm. Journal of Political Economy, 88(2), 288-307.

FIsHer, I. S. (1919): The Nature of Capital and Income. New York: Macmillan.

FISHeR, I. S. (1930): The Theory of Interest. As Determined by Impatience to Spend Income and Opportunity to Invest It. New York: Macmillan.

Fontana, M. - Marchionatti, R. (2007): Endogenous Animal Spirits and Investment. An Agentbased Model. Working Paper Series, Università di Torino.

Friedman, M. - Savage, L. (1948): The Utility Analysis of Choices Involving Risk. Journal of Political Economy, 56(4), 279-304.

Friedman, M. (1953): The Methodology of Positive Economics. In: Friedman, M.: Essays in Positive Economics. Chicago: University of Chicago Press, 3-43.

Fuller, J. - Jensen, M. C. (2002): Just Say to Wall Street: Putting a Stop to the Earnings Game. Journal of Applied Corporate Finance, 4, 41-46.

Gerrard, B. (1994): Animal Spirits. In: Arestis, P. - Sawyer, M. (eds): The Elgar Companion to Radical Political Economy. Cheltenham: Edward Elgar.

Gneezy, U. - List, J. A. - Wu, G. (2006): The Uncertainty Effect: When A Risky Prospect is Valued Less Than Its Worst. Possible Outcome. Quarterly Journal of Economics, 121(4), 1283-1309.

Hamouda, O. F. - Smithin, J. N. (1988): Some Remarks on "Uncertainty and Economic Analysis". The Economic Journal, 98, 159-164.

Harvey, J. (2008): Financial Risk Management. Topic Gateway Series, 47.

Havas, Á. (1993): Kockázatelemzés - mágia vagy tudomány? Iskolakultúra, 3(23), 21-28.

Hayek, F. A. (1945): The Use of Knowledge in Society. American Economic Review, 35(5), 19-30.

HAynes, J. (1895): Risk as an economic factor. The Quarterly Journal of Economics, 9(4), 409-449.

Hicks, J. R. (1931): The Theory of Uncertainty and Profit. Economica, 32(2), 170-189.

Hirshleifer, J. - Riley, J. G. (1979): The Analytics of Uncertainty and Information - An Expository Survey. Journal of Economic Literature, 17, 1422-1441.

Hodgson, G. M. (2011): The Eclipse of Uncertainty Concept in Mainstream Economics. Journal of Economic Issues, 45(1), 159-176.

Hume, D. (1739): A Treatise on Human Nature. Edinburgh.

Jensen, M. C. (2005): Agency Costs of Overvalued Equity. Financial Management 1, 519. 
Jeronimo, H. M. (2014): Risicophrenia and "animal spirits": clarifying the notions of risk and uncertainty in environmental problems. Scientiae Studia, 12, No spec. Sao Paulo.

Jevons, W. S. (1871): The Theory of Political Economy. London, New York: Macmillan

Kahneman, D. (1979): Prospect Theory: An Analysis of Decision Under Risk. Econometrica, 47(2), 263-291.

Keynes, J. M. (1910): Six lectures to London School of Economics. In: Indian Currency and Finance.

Keynes, J. M. (1921): The treatise on probability. London: Mac Millan

Keynes, J. M. (1925; 1979): A Treatise on money. Part 2. The Applied Theory of Money.

Keynes, J. M. (1937): The General Theory of Employment. Quarterly Journal of Economics, 51, 209223.

Keynes, J. M. (1937; 1979): Some economic consequences of a declining population. Eugenics Review, 29(1).

Keynes, J. M. (1979): Collected Works. Cambridge University Press.

Keynes, J. M. (1983): Collected Writings. Investment and Editorial Economic Articles and Correspondence. New York: Mac Millan.

KirkPATRICK, G. (2009): Corporate Governance: Lessons from the Crisis. OECD Journal: Financial Market Trends, June 61-87.

Kirzner, I. M. (1973): Competition and Entrepreneurship. Chicago, London: University of Chicago Press.

Kirzner, I. M. (1997): Entrepreneurial Discovery and the Competitive. Market Press: An Austrian Approach. Journal of Economic Literature, 35(3), 60-85.

Knight, F. H. (1921): Risk, Uncertainty and Profit. Boston: Houghton Miffin Company.

Koppl, R. - Moggridge, D. - Ozava, T. (1992): Correspondance. Journal of Economic Perspectives, 6(3), 207-212.

Koppl, R. (1991): Retrospectives Animal Spirits. Journal of Economic Perspectives, 5, 203-210.

Kovács, K. (2020): Relative consumption with multiple reference points under uncertainty. Economics and Sociology, 13(4), 61-80.

KregeL, J. A. (1976): Economic Methodology in the Face of Uncertainty: The Modelling Methods of Keynes and the Post-Keynesians. Economic Journal, 86(2), 209-225.

Langlois, R. N. - Cosgel, M. M. (1993): Frank Knight on Risk Uncertainty and the Firm: a New Interpretation. Economic Inquiry, 31, 456-465.

Lawson, T. (1985): Uncertainty and Economic Analysis. Economic Journal, 95, 909-927.

Lawson, T. (1988): Probability and Uncertainty in Economic Analysis. Journal of Post-Keynesian Economics, 11(1), 38-65.

Le Roy, S. F. - SingeLL, D. (1987): Knight on Risk and Uncertainty. Journal of Political Economy, 95, 394-406.

Loewenstein, G. - Thaler, R. H. (1989): Intertemporal Choice. Journal of Economic Perspectives, 3(4), 181-193.

Loomes, G. - Sugden, R. (1986): Disappointment and Dynamic Consistency in Choice Under Uncertainty. Review of Economic Studies, 53(2), 271-282.

Lucas, R. (1977): Understanding business cycles. Carnegie Rochester Conference Series Public Policy, Elsevir 5(1), 7-29.

LuCAs, R. (1980): Methods and Problems in Business Cycle Theory. Journal of Money, Credit and Banking, 12(4), 696-715.

Marchionatti, R. (1999): On Keynes Animal Spirits. Kyklos, 52(3), 415-439. 
Markowitz, H. (1952): Portfolio Selection. Journal of Finance, 7, 77-91.

Markowitz, H. (1952): The Utility of Wealth. Journal of Political Economy, 60, 151-158.

Markowitz, H. M. (1959): Portfolio Selection: Efficient Diversification of Investments. New York: John Wiley and Sons

Markowitz, H. M. (1991): Foundations of Portfolio Theory. Journal of Finance, 46(6), 469-477.

Meltzer, A. H. (1982): Rational Expectations, Risk, Uncertainty and Market Responses. In WaChtel, P. (ed.): Crises in the Economic and Financial Structure. Washington DC: Rowman \& Littlefield, Lexington Books.

MilL, J. S. (1885): Principles of Political Economy with of their applications to social philosophy. New York: Oxford University Press.

Mises, R. v. (1928/1957): Probability, Statistics and Truth. English Edition. London: George Allen and Unwin.

Moggridge, D. (1992): The Source of Animal Spirits. Journal of Economic Perspectives, 6(3), 207-209.

Moscati, I. (2016): Retrospectives: How Economist Came to Accept Expected Utility Theory: The Case of Samuelson and Savage. Journal of Economic Perspectives, 30(2), 219-236.

Мотосu, M. (2009): Managementul riscului în economie. Cluj-Napoca: Risoprint, 14.

Neumann, J. - Morgenstern, O. (1944): Theory of Games and Economic Behavior. Princeton University Press.

Neumann, J. (1937; 1965): A Model of General Economic Equilibrium. Review of Economic Studies, $13,1-9$.

Neumann, J. (1928): Zur Theoriie der Gesellschaftsspiele. Matematische Annalen, 100, 295-320.

O' Donnell, R. (1990): An overview of probability, expectations, uncertainty and rationality in Keynes's conceptual framework. Review of Political Economy, 2(3), 253-266.

O’ Donoghue, T. - Rabin, M. (1999): Doing It w or Later. American Economic Review, 89(1), 103-124.

Oxford English Dictionary (2008): Online edition: Risk and Uncertainty szócikk. Oxford University Press.

Park, K. F. - Shapira, Z. (2017): Risk and Uncertainty. The Palgrave Encyclopedia of Strategic Management. 250-251.

Pigou, A. C. (1920): The Economics of Welfare. London: Macmillan.

Rabin, M. - Thaler, R. H. (2001): Anomalies: Risk Aversion. Journal of Economic Perspectives, 15(1), 219-232.

Ricardo, D. (1821): On the Principles of Political Economy and Taxation ( $3^{\text {rd }}$ edition). London: Murray.

Roggi, O. - Ottanelli, O. (2013): An Evolutionary Perspective on the concept of risk, uncertainty and risk management. In Roggi, O. - Altman, E. (eds.): Managing and Measuring Risk. World Scientific Series in Finance, 5.

Roser, D. (2017): The Irrelevance of the Risk - Uncertainty Distinction. Science Engeneeiring Ethics 23, 1487-1407.

Rudd, A. - Clasing, H. K. (1982): Modern Portfolio Theory: the Principles of Investment Management. Homewood Illinois Dow Jones Irvin.

Runde, J. (1990): Keynesian Uncertainty and the Weight of Arguments. Economics and Philosophy 6(2), 275-292.

Runde, J. (1998): Clarifying Frank Knight's Discussion of the Meaning of Risk and Uncertainty. Cambridge Journal of Economics, 22(5), 539-546.

SAKAI, Y. (2015): J. M. Keynes versus F. H. Knight. How to deal with Risk, Probability and Uncertainty. Kyoto: Minerva Publishing Co. 
SAKAI, Y. (2018): On the Economics of Risk and Uncertainty. Shiga University, Discussion Paper Series, A-28, 26.

Samuelson, P. A. (1937): A Note of Measurement of Utility. Review of Economic Studies, 4, 155-161.

SAmuelson, P. A. (1947): Foundations of Economic Analysis. Harvard University Press.

Samuelson, P. A. (1963): Risk and Uncertainty: A Fallacy of Large Numbers. Scientia, 98, 108-113.

SAVAGE, L. (1954): The Foundation of Statistics. New York: Dover.

Schilirò, D. (2017): Economics versus psychology. Risk, uncertainty and the expected utility theory. MPRA Paper 83366, June 10. Department of Economics, University of Messina.

ShaCKLE, G. L. S. (1949): Expectation in Economics. Cambridge University Press

Shackle, G. L. S. (1967):The Years of High Theory: Invention and Tradition in Economic Thought 1926-1939. Cambridge University Press.

Shackle, G. L. S. (1972): Epistemics and Economics: A Critique of Economic Doctrines. Cambridge: Cambridge University Press.

Shane, F. - Loewenstein, G. - O’Donoghue, T. (2002): Time Discounting and Time Preferences: A Critical Review. Journal of Economic Literature, 40(2), 351-401.

Simon, H. A. (1955): A Behavioral Model of Rational Choices. Quarterly Journal of Economics, 69, 99-118.

Slutsky, E. (1915): On the Theory of the Budget of the Consumer. In: Stigler, G. J. - Bouldings, K. E. (ed., 1952): Reading in Price Theory. Illinois, Homewood, 2. chapter.

Sмiтh, A. (1956; 1776): An Inquiry into the Nature and Causes of Wealth of Nations. Chicago: P. F. Collier and Sons.

Starmer, C. (200o): Developments in n-Expected Utility Theory: The Hunt for a Descriptive Theory of Choice Under Risk. Journal of Economic Literature, 38, 332-382.

TALEB, N. (2007): The Black Swan: The Impact of the Highly Improbable. Random House.

Thaler, R. H. (1980): Toward a Positive Theory of Consumer Choice. Journal of Economic Behavior and Organization, 1(1), 39-6o.

Thaler, R. H. (1985): Mental Accounting and Consumer Choice. Marketing Science, 4(3), 199-214.

Toma, S. V. - Chitita, M. - SARpe, D. (2012): Risk and Uncertainty. Procedia Economics and Finance, 3, 975-980.

Townshend, H. (1937): Liquidity premium and the theory of value. Economic Journal, 47, 157-169.

Tversky, A. - Kahneman, D. (1981): The Framing on Decisions and the Psychology of Choice. Science, 211(4481), 453-458.

Tversky, A. - Kahneman, D. (1992): Advances in Prospect Theory: Cumulative Representation of Uncertainty. Journal of Risk and Uncertainty, 5(4), 297-323.

Vough, K. I. (1980): Economic Calculation Under Socialism: the Austrian Contribution. Economic Inquiry, 18(10), 535 .

WeIL, P. (1989): Increasing returns and animal spirits. American Economic Review, 79, 889-894.

Weintraub, E. R. (1975): Uncertainty and the Keynesian Revolution. History of Political Economy, 7, 530-548.

Willet, A. (1901): The Economic Theory of Risk and Insurance. University Press of Pacific. 